\title{
Facilitating Intergovernmental Dialogue: Judicial Review of the Division of Powers in the Supreme Court of Canada
}

Wade K. Wright

Follow this and additional works at: http://digitalcommons.osgoode.yorku.ca/sclr

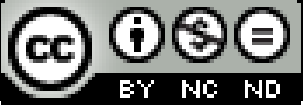

This work is licensed under a Creative Commons Attribution-Noncommercial-No Derivative Works 4.0 License.

\section{Citation Information}

Wright, Wade K.. "Facilitating Intergovernmental Dialogue: Judicial Review of the Division of Powers in the Supreme Court of Canada." The Supreme Court Law Review: Osgoode's Annual Constitutional Cases Conference 51. (2010).

http://digitalcommons.osgoode.yorku.ca/sclr/vol51/iss1/21 


\title{
Facilitating Intergovernmental Dialogue: Judicial Review of the Division of Powers in the Supreme Court of Canada
}

\author{
Wade K. Wright*
}

\section{INTRODUCTION}

A cursory review of any Canadian law review tells the story: the $\mathrm{Ca}$ nadian Charter of Rights and Freedoms ${ }^{1}$ is "in" and the division of powers is "out". Since 1982, when the Charter came into force, there has been a vast amount of writing about the Supreme Court of Canada's Charter decisions. However, its division of powers decisions, once the staple of constitutional law scholars, are now routinely ignored, particularly in English Canada. ${ }^{2}$ This trend has been noted before, with little effect. Writing at the turn of the century, Wayne MacKay, for example, lamented the lack of attention that constitutional law scholars now pay to the division of powers. ${ }^{3}$ Ten years later, however, the situation is not significantly different. The Supreme Court released a number of important division of powers decisions in this period. Some work has been done

Associate-in-Law, J.S.D. Candidate, Columbia Law School. This paper was completed in partial fulfilment of the degree of Doctor of the Science of Law (J.S.D.), Columbia Law School. I gratefully acknowledge the financial assistance of the Social Sciences and Humanities Research Council of Canada. Thanks are offered to Erin Delaney, Michael Dorf, Robin Elliot, Jamal Greene, Peter W. Hogg, Alex Irwin, Kirsti Mathers McHenry, Gillian Metzger and the Columbia Associates' Workshop for their helpful comments on earlier drafts of this paper. Any errors and omissions are, of course, my own. The paper reflects the law as of June 1, 2010.

Part I of the Constitution Act, 1982, being Schedule B to the Canada Act, 1982 (U.K.), 1982, c. 11 [hereinafter "Charter"].

The Supreme Court's division of powers decisions garner significantly more attention in the French-Canadian scholarship: see, e.g., E. Brouillet, La Négation de la Nation - L'identité Culturelle Québécoise et le Fédéralisme Canadien (Sainte-Foy, QC: Septentrion, 2005).

3 A.W. MacKay, "The Supreme Court of Canada and Federalism: Does/Should Anyone Care Anymore?" (2001) 80 Can. Bar Rev. 241, at 242 [hereinafter "MacKay, 'The Supreme Court of Canada and Federalism"']; see also D. Greschner, "The Supreme Court, Federalism and Metaphors of Moderation" (2000) 79 Can. Bar Rev. 47, at 48. 
discussing particular decisions and criticizing doctrinal developments; ${ }^{4}$ some decisions have been considered briefly in the context of discussions about a specific area of regulation (e.g., the environment) or issue (e.g., the scope of the spending power) ${ }^{5}$ but little has been written about the theory of judicial review ${ }^{6}$ that appears to be animating the Supreme Court's decision-making. ${ }^{7}$

This paper aims to fill this gap in the academic literature, by providing a novel account of the Supreme Court's theory of judicial review of the division of powers. Under this theory, the Supreme Court encourages the political branches to take the lead in defining the division of powers, by working out a mutually acceptable allocation of jurisdiction in each particular regulatory area. The Supreme Court limits itself primarily to facilitating intergovernmental dialogue about the division of powers and resolving the conflicts that result where the political branches fail to agree, and only secondarily to ensuring that neither order of government dramatically upsets the balance of power.

This theory of judicial review is gleaned from two sources. The first is the recent decision of the Supreme Court in Canadian Western Bank v. Alberta. ${ }^{8}$ In Canadian Western Bank, the majority of the Supreme Court

4 The gold standard remains P.W. Hogg, Constitutional Law of Canada, 5th ed. supp. (Toronto: Carswell, 2007) [hereinafter "Hogg, Constitutional Law of Canada"] (with yearly updates on the Supreme Court's constitutional decisions). The Supreme Court's division of powers decisions are also briefly reviewed in the annual "Developments in Constitutional Law" article published in the Supreme Court Law Review: see, e.g., C. Mathen, "Developments in Constitutional Law: The 2008-2009 Term" (2009) 48 S.C.L.R. (2d) 71.

See, e.g., P.W. Hogg, "Constitutional Authority Over Greenhouse Gas Emissions" (2009) 46 Alta. L. Rev. 507; (2008-2009) 34 Queen's L.J (various articles discussing the spending power).

I distinguish in this paper between theories of federalism and theories of judicial review. By theories of federalism, I mean theories that describe how governmental power ought to be allocated in a federal system. By theories of judicial review, I mean theories that describe the role, if any, that the courts ought to play in reviewing (and setting limits on) exercises of governmental power in a federal system.

The major exceptions are: E. Brouillet, "The Federal Principle and the 2005 Balance of Powers in Canada" (2006) 34 S.C.L.R. (2d) 308 [hereinafter "Brouillet, "The Federal Principle"']; B. Ryder, "The End of Umpire?: Federalism and Judicial Restraint" (2006) 34 S.C.L.R. (2d) 345 [hereinafter "Ryder, 'The End of Umpire?"']; G. Baier, "The Courts, the Division of Powers, and Dispute Resolution" in H. Bakvis \& G. Skogstad, eds., Canadian Federalism, 2d ed. (Oxford: Oxford University Press, 2008), at c. 2; G. Baier, "Judicial Review and Dispute Resolution", in H. Bakvis, G. Baier \& D. Brown, eds., Contested Federalism (Oxford: Oxford University Press, 2009), at c. 5; J. Leclair, "The Supreme Court of Canada's Understanding of Federalism" (2003) 28 Queen's L.J. 411; and J. Leclair, "The Elusive Quest for the Quintessential "National Interest"” (2005) 38 U.B.C. L. Rev. 355.

[2007] S.C.J. No. 22, [2007] 2 S.C.R. 3 (S.C.C.) [hereinafter "Canadian Western Bank"]. Canadian Western Bank was released concurrently with British Columbia (Attorney General) v. Lafarge Canada Inc., [2007] S.C.J. No. 23, [2007] 2 S.C.R. 86 (S.C.C.) [hereinafter "Lafarge"]. I 
significantly restricted the application of the doctrine of interjurisdictional immunity (described below). In doing so, it provided rare but important insight into its theory of judicial review. The decision has been discussed by several others; however, little if any substance has been written about the theory of judicial review described in, and animating, the decision. ${ }^{9}$ The second is the pre-Canadian Western Bank division of powers decisions of the Supreme Court under Chief Justice McLachlin (2000 to present) (the "McLachlin Court"). ${ }^{10}$ The theory of judicial review described in Canadian Western Bank was not new. The Supreme Court merely made explicit a theory of judicial review that had quietly been at work in its division of powers decisions for a number of years. ${ }^{11}$ Looked at in retrospect, and with the benefit of Canadian Western Bank, these decisions provide important insight into the theory of judicial review later outlined in Canadian Western Bank itself. ${ }^{12}$

focus here on the decision in Canadian Western Bank, because it contains the bulk of the majority's legal and theoretical analysis.

$9 \quad$ See R. Elliot, "Interjurisdictional Immunity after Canadian Western Bank and Lafarge Canada Inc.: The Supreme Court Muddies the Doctrinal Waters - Again" (2008) 43 S.C.L.R. (2d) 433, at 472 (noting that the theoretical aspect of the decision "warrants critical scrutiny", and expressly limiting this article to the decision's doctrinal aspects); P.W. Hogg \& R. Godil, "Narrowing Interjurisdictional Immunity" (2008) 42 S.C.L.R. (2d) 623 [hereinafter "Hogg \& Godil, "Narrowing Interjurisdictional Immunity"'] (focusing largely on doctrine); J.G. Furey, "Interjurisdictional Immunity: The Pendulum Has Swung" (2008) 42 S.C.L.R. (2d) 597 (focusing largely on doctrine); and E. Edinger, "Back to the Future with Interjurisdictional Immunity: Canadian Western Bank v. Alberta; British Columbia v. Lafarge Canada Inc" (2008) 66 Adv. 553 (focusing largely on doctrine).

${ }_{10}$ I limit my discussion to the division of powers decisions of the McLachlin Court, because this provided a convenient way of restricting my discussion. In doing so, I should not be taken as suggesting that the theory of judicial review that I describe is wholly unique to the McLachlin Court's division of powers decisions. Important aspects of the approach to the division of powers that I describe were evident in earlier Supreme Court division of powers decisions, including, in particular, the division of powers decisions of Chief Justice Dickson (1973-1990) and the Supreme Court during the tenure of Chief Justice Lamer (1990-2000). For discussion of the division of powers decisions of Dickson C.J.C., see, e.g., K. Swinton, The Supreme Court and Canadian Federalism (Toronto: Carswell, 1990), at c. 10 [hereinafter "Swinton, The Supreme Court and Canadian Federalism"]; J.T. Saywell, The Lawmakers: Judicial Power and the Shaping of Canadian Federalism (Toronto: University of Toronto Press, 2002), at c. 11; and G. Baier, Courts and Federalism: Judicial Doctrine in the United States, Australia and Canada (Vancouver: University of British Columbia Press, 2006), at c. 5 [hereinafter "Baier, Courts and Federalism"]. For discussion of the division of powers decisions of the Supreme Court under Lamer C.J.C., see MacKay, "The Supreme Court of Canada and Federalism", supra, note 3; Saywell, The Lawmakers, at c. 11; and Baier, Courts and Federalism, at c. 5.

${ }_{11}$ Some of these decisions are discussed in the sources listed in note 7. However, these sources tend to overlook or underestimate the role that intergovernmental dialogue plays in the decisions.

${ }_{12}$ Two important exceptions should be noted. First, I consider only the decisions (or parts of the decisions) dealing with the division of powers in ss. 91 and 92 of the Constitution Act, 1867 (U.K.), 30 \& 31 Vict., c. 3, reprinted in R.S.C. 1985, App. II, No. 5. Second, I do not consider the division of powers decisions that touch upon, directly or indirectly, s. 91(24), the federal legislative power over "Indians, and Lands reserved for the Indians". (The decisions are: Lovelace v. Ontario, 
The notion of intergovernmental dialogue figures prominently in this theory of judicial review. Dialogue is a term that is now ubiquitous in writing about constitutional law in Canada and elsewhere. ${ }^{13}$ In Canada, it has been used mostly in connection with cases decided under the Charter. ${ }^{14}$ In that connection, it has been taken to refer, narrowly, to the ability of the competent legislative body to respond, legislatively, to a judicial decision striking down a law for violating the Charter. ${ }^{15}$ I used the term in that narrower sense in a previous paper. ${ }^{16}$ But the term dialogue also can, and has, been used in a broader sense, to describe the interactions that occur between the various branches of government (and indeed society as a whole) in the area of constitutional decision-making. ${ }^{17}$ I use the term in that broader sense in this paper. ${ }^{18}$ However, unlike the dialogue that occurs in connection with the Charter, which is in large measure intragovernmental (or horizontal), the dialogue that I describe here is

[2000] S.C.J. No. 36, [2000] 1 S.C.R. 950 (S.C.C.) [hereinafter "Lovelace"]; Kitkatla Band v. British Columbia (Minister of Small Business, Tourism and Culture), [2002] S.C.J. No. 33, [2002] 2 S.C.R. 146 (S.C.C.) [hereinafter "Kitkatla Band"]; Paul v. British Columbia (Forest Appeals Commission), [2003] S.C.J. No. 34, [2003] 2 S.C.R. 585 (S.C.C.) [hereinafter "Paul"]; and R. v. Morris, [2006] S.C.J. No. 59, [2006] 2 S.C.R. 915 (S.C.C.) [hereinafter "Morris"].) These cases raise unique and difficult issues - in particular, issues of self-government and the interaction between s. 91(24) and s. 88 of the federal Indian Act, R.S.C. 1985, c. I-5, which operates to make certain otherwise constitutionally inapplicable provincial laws applicable to "Indians" - not encountered in the other division of powers cases; for that reason, my view is that they ought to be addressed separately. See B. Ryder, "The Demise and Rise of the Classical Paradigm in Canadian Federalism" (1990-1991) 36 McGill L.J. 308, at 362-80 [hereinafter "Ryder, "The Demise and Rise of the Classical Paradigm"”] (advocating a unique approach to s. 91(24) cases).

${ }_{13}$ See C. Bateup, "The Dialogic Promise: Assessing the Normative Potential of Theories of Constitutional Dialogue" (2005-2006) 71 Brook. L. Rev. 1109, at 1109 [hereinafter "Bateup, 'The Dialogic Promise"'] (describing dialogue as ubiquitous).

${ }_{14}$ But see J. Kelly \& M. Murphy, "Shaping the Constitutional Dialogue on Federalism" (2005) 35(2) Publius 217 (using the term in connection with the Supreme Court's Aboriginal rights decisions and its decision in the Reference re Secession of Quebec, [1998] S.C.J. No. 61, [1998] 2 S.C.R. 217 (S.C.C.) [hereinafter "Quebec Secession Reference"]).

P.W. Hogg \& A.A. Bushell, "The Charter Dialogue Between Courts and Legislatures (Or Perhaps the Charter of Rights Isn't Such A Bad Thing After All)" (1997) 35 Osgoode Hall L.J. 75.

${ }_{16}$ P.W. Hogg, A.A. Bushell Thornton \& W.K. Wright, "Charter Dialogue Revisited - Or Much Ado About Metaphors" (2007) 45 Osgoode Hall L.J. 1, at 45.

${ }_{17}$ The dialogue literature is sizeable. For a good summary, see C. Bateup, "The Dialogic Promise", supra, note 13; and C. Bateup, "Expanding the Conversation: American and Canadian Experiences of Constitutional Dialogue in Comparative Perspective" (2007) 21 Temp. Int. \& Comp. L.J. $1_{\text {is }}$

is The manner in which my colleagues and I used the term dialogue in "Charter Dialogue Revisited" has been criticized: see, for example, C. Bateup, "The Dialogic Promise", id. It is beyond the scope of this paper to respond to this criticism here, but briefly, my view that there is no necessary inconsistency between the narrow and broad definitions of dialogue. The trend described in that article remains, in my view, an important part of the dialogue story, but it is not, I accept, the only story. 
primarily intergovernmental (or vertical). ${ }^{19}$ By dialogue, I mean the federal-provincial agreement, not judicial-legislative and/or judicialexecutive agreement, about particular exercises of legislative power that the Supreme Court seems intent on facilitating.

The paper is organized in three main parts. In Part II, I outline the basic features of the theory of judicial review described in Canadian Western Bank. I then discuss how this theory is reflected in the account of division of powers doctrine provided in the decision. In Part III, I analyze the key pre-Canadian Western Bank division of powers decisions. I demonstrate how the theory of judicial review described in Part II is reflected in these decisions, and also comb the decisions for further insight into this theory of judicial review. In Part IV, I anticipate three potential criticisms of this theory of judicial review, and a possible answer to these criticisms. I demonstrate the importance of these criticisms by referring to several recent cases that have reached the Supreme Court.

\section{FACILITATING INTERGOVERNMENTAL DIALOGUE: CANADIAN WESTERN BANK V. ALBERTA}

In Canada, the banking industry falls within federal jurisdiction, under the federal power over "Banking" (section 91(15)), and the insurance industry falls within provincial jurisdiction, under the provincial power over property and civil rights (section 92(13)). Traditionally, banks were not authorized to promote or to sell insurance. However, in 1991, Parliament amended the federal banking legislation ${ }^{20}$ in order to permit banks to promote, but not sell, various types of creditors' insurance, all of which, in some form or another, secured various types of bank loans. Following these amendments, the issue became whether banks would be required to comply with the existing web of provincial legislation regulating the insurance industry. The Province of Alberta left no room for doubt. It amended its insurance legislation, ${ }^{21}$ requiring banks that promoted insurance in Alberta to comply with certain licensing and consumer protection requirements.

19 I say primarily because the courts still play a role, but that role is secondary and facilitative. See K. Swinton, "Federalism Under Fire: The Role of the Supreme Court of Canada" (1992) 55 Law \& Comtemp. Probs. 121, at 138 [hereinafter "Swinton, 'Federalism under Fire"'] (suggesting that the Supreme Court "has a role to play in managing conflict and change in the federalism system, but its role is secondary and, ideally, facilitative").

20 Bank Act, S.C. 1991, c. 46 (and related regulations).

21 Insurance Act, R.S.A. 2000, c. I-3 (and related regulations). 
Several large banks responded by seeking a declaration that banks that promoted insurance in Alberta did not need to comply with these requirements. ${ }^{22}$ On appeal, the Supreme Court refused to grant the declaration. Justices Binnie and LeBel, writing for six of the seven judges that sat on the case, ${ }^{23}$ emphasized that " $[\mathrm{t}]$ he fact that Parliament allows a bank to enter into a provincially regulated line of business ... cannot ... unilaterally broaden the scope of the exclusive legislative power granted by the Constitution Act, 1867." Rather, banks that take part in provincially regulated activities will, they stressed, be required to comply with all applicable federal and provincial legislation. ${ }^{24}$

\section{The Supreme Court's Theory of Judicial Review}

The Supreme Court's division of powers cases are typically grounded largely in formalistic legal reasoning, in references to text, doctrine and precedent. However, in Canadian Western Bank, in three brief paragraphs, Binnie and LeBel JJ. felt moved to reflect on Canadian federalism. Their discussion provides unusual but interesting insight into the Supreme Court's theory of judicial review in division of powers cases.

\section{(a) "The Principle of Federalism"}

Under the heading "The Principle of Federalism", Binnie and LeBel JJ. suggest, in one paragraph, and with little explanation or support (judi-

22 The banks relied heavily on Bank of Nova Scotia v. Canada (Superintendent of Financial Institutions), [2003] B.C.J. No. 92, 11 B.C.L.R. (4th) 206 (B.C.C.A.), leave to appeal refused [2003] S.C.C.A. No. 229, [2003] 3 S.C.R. viii (S.C.C.).

${ }_{23}$ Strictly speaking, at present, the reasoning in Canadian Western Bank, supra, note 8, can be said to represent the views of only eight of the nine members of the Supreme Court: Binnie and LeBel JJ., who wrote the decision; McLachlin C.J.C. and Fish, Abella and Charron JJ., who concurred in the decision; Deschamps J., who did not sit on Canadian Western Bank, but who concurred in the decision in Lafarge, supra, note 8, in which Binnie and LeBel JJ., writing for the majority, explicitly adopted their reasoning in Canadian Western Bank; and Rothstein J., who did not sit on either Canadian Western Bank or Lafarge, but who did concur in the Supreme Court's recent unanimous judgment in Chatterjee v. Ontario (Attorney General), [2009] S.C.J. No. 19, [2009] 1 S.C.R. 624 (S.C.C.) [hereinafter "Chatterjee"], in which it explicitly affirmed its reasoning in Canadian Western Bank (see id., para. 2). Justice Bastarache wrote a concurring opinion in both Canadian Western Bank and Lafarge. Although he did not disagree with the result in either case, he did disagree with Binnie and LeBel JJ.'s reasoning on the doctrine of interjurisdictional immunity and the doctrine of paramountcy. Jutsice Bastarache has now retired and been replaced by Cromwell J. of the Nova Scotia Court of Appeal. At present it remains unclear whether he agrees with the views expressed by the majority in Canadian Western Bank.

${ }^{24}$ Canadian Western Bank, supra, note 8, at para. 4. 
cial or academic), that Canadian federalism had, and still has, three "fundamental objectives". ${ }^{25}$ The first will be familiar to those with some knowledge of the Supreme Court's previous division of powers decisions: this is the idea that federalism in Canada was a "legal response" to the "political and cultural realities that existed at Confederation", a mechanism for reconciling the diversity of the "original members" with the desire for national unity. ${ }^{26}$ The second is also not entirely unfamiliar: this is the idea that a "fundamental objective" of federalism in Canada was, and is, to "promote democratic participation by reserving meaningful powers to the local or regional level". ${ }^{27}$ The third, though, will be unfamiliar: this is the idea that a "fundamental objective" of federalism in Canada was, and is, "to foster co-operation among governments and legislatures for the common good". ${ }^{28}$

In the next paragraph, Binnie and LeBel JJ. then suggest that, in order to attain these three fundamental objectives, "a certain degree of predictability with regard to the division of powers between Parliament and the provincial legislatures is essential". ${ }^{29}$ But foreshadowing the changes they introduce to the doctrine of interjurisdictional immunity, they also indicate that the interpretation of the division of powers "must evolve and must be tailored to the changing political and cultural realities of Canadian society". ${ }^{30}$

Justices Binnie and LeBel then make three points about the key division of powers doctrines. First, these doctrines "permit an appropriate

$25 \quad$ Id., at para. 22.

26 See Quebec Secession Reference, supra, note 14, at para. 43 ("The federal-provincial division of powers was a legal recognition of the diversity that existed among the initial members ..., and manifested a concern to accommodate that diversity within a single nation"); see also Maritime Bank of Canada (Liquidators of) v. New Brunswick (Receiver-General), [1892] J.C.J. No. 1, [1892] A.C. 437 , at 441-42 (P.C.).

${ }_{27} \quad$ See Quebec Secession Reference, id., at para. 58 ("The federal structure of our country also facilitates democratic participation by distributing power to the government thought to be most suited to achieving the particular societal objective ...").

28 Canadian Western Bank, supra, note 8, at para. 22. For a similar claim from the High Court of Australia about the Australian Constitution, see R. v. Duncan; Ex parte Australian Iron and Steel Pty. Ltd. (1983), 158 C.L.R. 535, 589 (H.C.A.), per Deane J. (noting that cooperation is a "positive objective of the [Australian] Constitution"); and R. v. Hughes, [2000] 202 C.L.R. 535, at para. 53 (H.C.A.), per Kirby J. (referring to cooperation as an "elemental feature of the federal system of government"); see also Gould v. Brown (1998), 193 C.L.R. 346, at para. 277 (H.C.A.), per Kirby J.; but see Re Wakim; Ex parte McNally (1999), 198 C.L.R. 511, at 556 (H.C.A.), per McHugh J. ("co-operative federalism is not a constitutional term. It is a political slogan, not a criterion of constitutional validity or power. ... Where constitutional power does not exist, no cry of cooperative federalism can supply it").

$29 \quad$ Canadian Western Bank, id., at para. 23.

$30 \quad$ Id. 
balance to be struck" between the "inevitable overlap" in jurisdiction "while recognizing the need to preserve sufficient predictability in the operation of the division of powers". ${ }^{31}$ Second, these doctrines "must also be designed to reconcile the legitimate diversity of regional experimentation with the need for national unity". 32 Finally, these doctrines must "include a recognition that the task of maintaining the balance of powers in practice falls primarily to governments", and that they "must facilitate, not undermine ... 'co-operative federalism,", 33

In a few short paragraphs, and with relatively little fanfare, the Supreme Court provides important insight into its theory of judicial review of the division of powers. On my reading, three key ideas figure particularly prominently in this theory of judicial review. The first is deference to the political branches, the idea that the Supreme Court will accommodate the fact that "the task of maintaining the balance of powers in practice falls primarily to governments". ${ }^{34}$ The second is what I call intergovernmental dialogue, the idea that the Supreme Court will work to facilitate "co-operative federalism", which I take to mean "co-operation among governments and legislatures for the common good". The third is predictability, the idea that "a certain degree of predictability with regard to the division of powers between Parliament and the provincial legislatures is essential".

These three ideas are discussed in more detail in the three sections that follow.

\section{(b) Deference to the Political Process}

There are, roughly speaking, two views of the role of the courts in a federal system. The traditional view is that the courts play a necessary role in a federal system. ${ }^{37}$ Advocates of this view, in Canada and else-

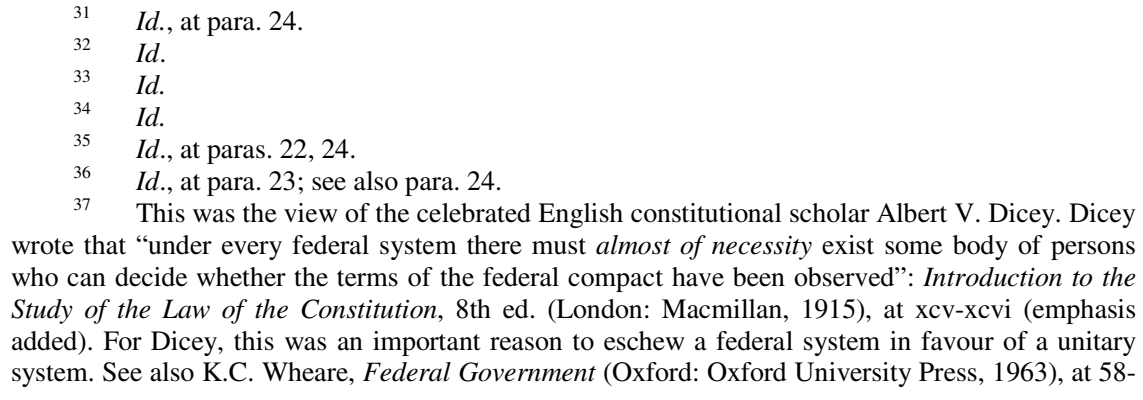

This was the view of the celebrated English constitutional scholar Albert V. Dicey. Dicey wrote that "under every federal system there must almost of necessity exist some body of persons who can decide whether the terms of the federal compact have been observed": Introduction to the Study of the Law of the Constitution, 8th ed. (London: Macmillan, 1915), at xcv-xcvi (emphasis added). For Dicey, this was an important reason to eschew a federal system in favour of a unitary system. See also K.C. Wheare, Federal Government (Oxford: Oxford University Press, 1963), at 58- 
where, often do not attempt to justify it; judicial review is simply assumed to be a necessary element of a federal system. ${ }^{38}$ However, those who do attempt to justify this view often place considerable weight on the argument that the political process cannot be trusted to protect the federal balance. $^{39}$

The alternative view is that the courts have little (if any) role to play in protecting the federal balance. One argument commonly made for this view is that judicial review is undesirable, because decision-making in division of powers cases is inescapably political, and accordingly ought to be left to politics. This argument is prominent in the Canadian academic literature. ${ }^{40}$ Another argument commonly made for this view is that judicial review is unnecessary, because the "political safeguards of federalism" (certain structural features of the political process) reduce the need for judicial oversight of the federal balance. This argument is particularly prominent in the United States. ${ }^{41}$

In Canadian Western Bank, the Supreme Court demonstrated considerable sympathy for the second view, that judges in a federal system have

66; and W.S. Livingston, Federalism and Constitutional Change (London: Clarendon, 1956), at 1011.

38 Ryder, "The End of Umpire?", supra, note 7, at 347 (making a similar observation).

In Canada, see K. Swinton, The Supreme Court and Canadian Federalism, supra, note 10, at 40-55 (focusing on the shortcomings of the political process in criticizing the argument of several Canadian commentators that the courts properly have a very limited role to play in federalism cases). In the United States, see Saikrishna B. Prakash \& John C. Yoo, "The Puzzling Persistance of Process-Based Federalism Theories" (2001) 79 Tex. L. Rev. 1459; Lynn A. Baker \& Ernest A. Young, "Federalism and the Double Standard of Judicial Review" (2001) 51 Duke L.J. 75; Marci A. Hamilton, "Why Federalism Must Be Enforced: A Response to Professor Kramer" (2001) 46 Vill. L. Rev. 1069.

40 P. Weiler, In The Last Resort: A Critical Study of the Supreme Court of Canada (Toronto: Carswell, 1974) [hereinafter "Weiler, In the Last Resort"], at c. 6 (arguing that judicial review of federalism issues should be limited to determining whether: (a) there is a direct conflict between federal and provincial legislation; and (b) provincial action discriminates against extra-provincial products and citizens, because, in part, the judiciary lacks the competence to deal with federalism issues); and P. Monahan, "At Doctrine's Twilight: The Structure of Canadian Federalism" (1984) 23 U.T.L.J. 47 (arguing that, because federalism issues are inescapably political, they should be left to the political process); but see P. Monahan, Politics and the Constitution (Toronto: Carswell, 1987) (arguing that judicial review of federalism issues might not be a problem after all, because federalism decisions typically have very little real impact in practice).

${ }_{41}$ See H. Wechsler, "The Political Safeguards of Federalism: The Role of the States in the Composition and Selection of the National Government" (1954) 54 Colum. L. Rev. 543; J. Choper, Judicial Review and the National Political Process (Chicago: University of Chicago Press, 1980); and L. Kramer, "Putting the Politics Back into the Political Safeguards of Federalism" (2000) 100 Colum. L. Rev. 215 [hereinafter "Kramer, 'Putting the Politics Back"']. This argument was adopted by the majority of the United States Supreme Court in Garcia v. San Antonio Metropolitan Transit Authority, 469 U.S. 528, 550 (1985), but was implicitly rejected in later cases: see John C. Yoo, "The Judicial Safeguards of Federalism" (1997) 70 S. Cal. L. Rev. 1311. 
a limited role to play in protecting the federal-provincial balance of power. This is succinctly illustrated in one brief passage, in which the Supreme Court suggests that decision-making in division of powers cases must "recognize" and, in turn, accommodate the fact that "the task of maintaining the balance of powers in practice falls primarily to governments". ${ }^{42}$

Notice the language used by the Supreme Court: on the one hand, the Supreme Court clearly indicates that it intends to let the task of setting the balance of powers fall primarily to governments; restraint will be its posture in division of powers cases. On the other hand, the Supreme Court does not say that the task of setting the balance of powers falls $e x$ clusively to governments; indeed, earlier in the same paragraph, it refers to the courts as the "the final arbiters of the division of powers". ${ }^{43}$ It says, rather, that the task of setting the balance of powers will fall primarily to governments. The Supreme Court clearly still believes that it still has some role to play in division of powers cases.

The Supreme Court did not explicitly justify this posture of restraint in division of powers cases in the decision itself. It did, however, provide a case reference that does, on further examination, shed some light on its thinking. The reference is to a paragraph in the Supreme Court's unanimous judgment in the Employment Insurance Reference. ${ }^{44}$ In that paragraph, Deschamps J., for the Supreme Court, provided an unusually candid assessment of judicial decision-making in division of powers cases. She wrote that judicial decision-making in division of powers cases "will often depend on a given court's view of what federalism is. What are regarded as the characteristic features of federalism may vary from one judge to another, and will be based on political rather than legal notions". ${ }^{45}$ In the very next sentence, she then wrote that " $[\mathrm{t}]$ he task of maintaining the balance between federal and provincial powers falls primarily to governments." 46

In this passage, the idea that it is appropriate to defer to the political branches in division of powers cases is juxtaposed with the idea that decision-making in division of powers cases will often be informed by a

\footnotetext{
42 Canadian Western Bank, supra, note 8, at para. 24.

$43 \quad I d$., at para. 24.

44 Reference re Employment Insurance Act (Can.), ss. 22 and 23, [2005] S.C.J. No. 57, [2005] 2 S.C.R. 669 (S.C.C.) [hereinafter "Employment Insurance Reference"].

45 Id., at para. 10.

46 Id. This passage is discussed in H. Kong, "The Forms and Limits of Federalism Doctrine" (2007-2008) 13 Rev. Const. Stud. 241, at 264-65.
} 
particular vision of federalism, a vision that will, in turn, often be informed by political, not legal considerations. ${ }^{47}$ Although the Supreme Court does not say so explicitly, the implication is clear. The Supreme Court worries that any line that it might draw between federal and provincial legislative power will be informed by politics. For that reason, it is considerably more comfortable leaving such line-drawing exercises to the political branches, as much as possible.

\section{(c) Facilitating "Cooperative Federalism"}

The first idea that figures prominently in Canadian Western Bank, then, is that the Supreme Court, in division of powers cases, will act with restraint, and defer to the political branches. This is important, but it is only part of the picture. The Supreme Court also makes it clear in Canadian Western Bank that it is not prepared to be entirely passive in its division of powers decisions: that it is content to let the political branches take the lead in defining the division of powers, but that it will also work

47 Eugénie Brouillet suggests that this passage "illustrates the absence of a federal theory" in the Supreme Court: see "The Federal Principle", supra, note 7, at 320. I do not agree.

In my view, theories of federalism (and remembering the distinction I draw between theories of federalism and theories of judicial review) can be organized roughly into two groups: substantive theories of federalism and process theories of federalism. Substantive theories of federalism work from the fundamental premise that there is an ideal (and for some, a permanently fixed) balance of power between the federal government and the provincial governments. Substantive theories dominate the Canadian scholarship about federalism (although recent advocates are more likely to concede that the boundaries of legislative power, whatever they may be, leave generous space for legislative discretion). Unfortunately, in a good deal of this scholarship, very little attempt is made to justify why a particular balance of power is ideal - a balance of power is simply asserted as ideal and a particular allocation of power is criticized (or defended) on the basis that it is inconsistent (or consistent) with this ideal balance of power. However, where an attempt is made to justify a particular balance of power, an appeal is often made to original intent (the original bargain struck by the framers of the division of powers) and/or one or more of the values that federalism is thought to serve (these include, usually, democracy, efficiency and/or autonomy).

Process theories of federalism, in contrast, work from the fundamental premise that there is no objectively ideal balance of power. Advocates of process theories of federalism do not necessarily deny that federalism may serve particular values, but they do argue that it is not possible to glean an ideal balance of power from these values because reasonable people will disagree, first, about the values that federalism actually serves, and second, about the weight to be placed on those values. In the absence of a substantive theory, process theorists look to the political branches to set the balance of power, and resolve jurisdictional disputes. See A. Stone, "Judicial Review Without Rights: Some Problems for the Democratic Legitimacy of Structural Judicial Review" (2008) 28 O.J.L.S. 1 (arguing that those who hold democracy-based objections to constitutional rights should reconsider, and perhaps oppose, federal judicial review).

The Supreme Court does seem to have a theory of federalism - a process theory called "cooperative federalism", discussed below. With that said, it would seem that the Supreme Court cannot quite bring itself to abandon the idea that there are fixed boundaries on legislative power that it needs to patrol. 
to facilitate a particular model of political-branch-driven federalism, called "cooperative federalism". ${ }^{48}$

What does the Supreme Court mean by cooperative federalism? Unfortunately, the Supreme Court does not tell us. However, cooperative federalism appears to refer, at a minimum, to a federalism in which the federal and provincial governments agree to exercises of jurisdiction in particular regulatory areas, without recourse to the courts.

This can be gleaned from two sources. The first is a reference, in the decision itself, to a passage in the dissenting reasons of Iacobucci J. in Husky Oil Operations Ltd. v. M.N.R. ${ }^{49}$ In that passage, Iacobucci J. referred to the "theory of 'co-operative federalism' upon which (particularly postwar) Canada has been built". As in Canadian Western Bank, Iacobucci J. did not define what he meant by cooperative federalism. However, the term cooperative federalism is ubiquitous in the academic literature. Like Iacobucci J., academic commentators generally use the term to describe the division of powers as it has operated in Canada, in particular areas, and at particular times. ${ }^{50}$ The term is used by some commentators in a broad sense, by others in a narrow sense. In its broader sense, cooperative federalism typically refers to a federalism in which the federal and provincial governments agree to the exercise of federal and provincial legislative power in particular policy areas, without resorting to litigation, ${ }^{51}$ by relying

48 Canadian Western Bank, supra, note 8, at para. 24.

49 [1995] S.C.J. No. 77, [1995] 3 S.C.R. 453, para. 162 (S.C.C.).

50 See, e.g., Hogg, Constitutional Law of Canada, supra, note 4, at 6.9 ("In Canada, the centralized form of federalism which developed during and after the Second World War has been replaced by a form of cooperative federalism in which the provinces have autonomy to influence the outcome of federal provincial relationships"); G. Baier, "The EU's Constitutional Treaty: Federalism and Intergovernmental Relations - Lessons from Canada" (2005) 15(2) Reg. \& Fed. Studies 205, at 207-208 ("the Canadian federal system has been much more reliant on cooperative behaviour of governments").

The complete story is told in R. Simeon \& I. Robinson, State, Society, and the Development of Canadian Federalism (Toronto: University of Toronto Press, 1990), at c. 6-9.

51 W.R. Lederman, Continuing Constitutional Dilemmas: Essays on the Constitutional History, Public and Federal System of Canada (Toronto: Butterworths, 1981), at 300 [hereinafter "Lederman, Continuing Constitutional Dilemmas"] ("[t]he essence of co-operative federalism is federal-provincial agreement, whether tacit or explicit, about complementary uses of federal and provincial powers and resources"); and J. Cameron, "Federalism, Treaties, and International Human Rights under the Canadian Constitution" (2002) 48 Wayne L. Rev. 1, at 39:

[Co-operative federalism] describes a relationship between the executive branches of the two levels of government and is also referred to as "executive federalism." The relationship is one of direct negotiation between the "First Ministers" of the federal government and the provinces, and its object is to forge agreement on issues over which neither level of government has exclusive control or jurisdiction.

See also, from Australia, J. McConvill \& D. Smith, "Interpretation and Cooperative Federalism: Bond v. R. From a Constitutional Perspective" (2001) 29 Fed. L. Rev. 75, at 75 ("Co-operative fed- 
on a vast network of formal and informal mechanisms and relationships developed for this purpose. ${ }^{52}$ In its narrower sense, cooperative federalism is distinguished from collaborative federalism. Both refer to a federalism in which the federal and provincial governments agree to exercises of federal and/or provincial legislative power in particular policy areas. But with cooperative federalism, there is a hierarchy between the two orders of government: the federal government exercises a considerable degree of political and financial leadership. ${ }^{53}$ In contrast, with collaborative federalism, there is no such hierarchy between the two orders of government: the two orders of government work together as equals. ${ }^{54}$ This distinction between the narrow sense of cooperative federalism and collaborative federalism is discussed in the final section of the paper. For now, it is sufficient to note that intergovernmental agreement about the exercise of federal and provincial legislative power (what I call intergovernmental dialogue) is fundamental to cooperative federalism, in both its broad and narrow sense. By indicating its intention to facilitate cooperative federalism, the Supreme Court can be understood to be declaring its intention to facilitate intergovernmental dialogue about the exercise of federal and provincial legislative power.

This is confirmed by the second source of insight, the language of decision itself. Two passages in particular are illuminating. In the first, the Supreme Court suggests that one of three "fundamental objectives" of Canadian federalism was, and still is, "to foster co-operation among legislatures and governments for the common good". ${ }^{55}$ In the second, the Supreme Court suggests, referring back to these three "fundamental

eralism is the process by which the Commonwealth and the States organise for their overlapping constitutional powers to be exercised concurrently in order to achieve national outcomes through consensual processes").

52 Hogg, Constitutional Law of Canada, supra, note 4, at 5.8 ("The essence of cooperative federalism is a network of relationships between the executives of the central and regional governments. Through these relationships mechanisms are developed ... which allow a continuous redistribution of powers and resources without recourse to the courts or the amending process"); and D. Cameron \& R. Simeon, "Intergovernmental relations in Canada: The emergence of collaborative federalism" (2002) 32(2) Publius 49, at 50-51 [hereinafter "Cameron \& Simeon"] (linking "cooperative federalism" with the "relationships developed among provincial and federal officials and ministers within specific policy areas").

53 This is the sense in which the term is usually used in the U.S. literature: see, e.g., D. Elezar, "Cooperative Federalism" [hereinafter "Elezar, 'Cooperative Federalism"'] in D. Kenyon \& J.C. Kincaid, eds., Competition Among State and Local Governments (Washington: Urban Institute Press, 1991), at c. 4; and Philip J. Weiser, "Towards a Constitutional Architecture for Cooperative Federalism" (2001) N.C. L. Rev. 663.

$54 \quad$ Cameron \& Simeon, supra, note 52, at 49.

55 Canadian Western Bank, supra, note 8, at para. 22. 
objectives", that "the main constitutional doctrines ... should be construed so as to facilitate the achievement of the objectives of Canada's federal structure". ${ }^{56}$ The meaning of these two passages, taken together, is plain: the Supreme Court, in its division of powers decisions, will attempt to facilitate "co-operation among legislatures and governments for the common good" - in other words, intergovernmental dialogue. ${ }^{57}$

This is interesting. In acting with restraint, and accommodating broad exercises of jurisdiction, the Supreme Court seems to have in mind a model of federalism in which the two orders of government work out a mutually acceptable allocation of responsibility in each regulatory area. In practice, this might mean that, in some regulatory areas, the federal government will take the lead; in others, that the provincial governments will take the lead; and in still others, that the two orders of government will establish complementary regulatory schemes. Provided both orders of government agree to the allocation of responsibility, the Supreme Court seems content. It may be that it prefers agreement that results from actual direct negotiation and consultation. However, as I demonstrate below, with reference to several pre-Canadian Western Bank decisions, it also seems prepared to accept agreement that results indirectly, from an organic process of action and response, with legislative power exercised unilaterally, and the exercise of jurisdiction agreed to by the other level of government after the fact, in a court challenge.

What justification does the Supreme Court provide for this approach? The answer is - virtually none. The Supreme Court merely asserts that cooperative federalism ought to inform the division of powers as it operates in the courts. It is implicit in this assertion that, for the Supreme Court, intergovernmental cooperation is best suited to adapting the division of powers to a changing society and to resolving intergovernmental disputes about jurisdiction. But, the Supreme Court provides no justification for this assertion, by, say, grounding cooperative federalism in the text or history of the constitution or (with one exception, a reference to a dissent) the precedents of the Supreme Court. Similarly, it leaves unaddressed the competing view that cooperative federalism is

$56 \quad$ Id., at para. 24.

57 See also Quebec (Attorney General) v. Moses, [2010] S.C.J. No. 17, [2010] 1 S.C.R. 557, at para. 29 (S.C.C.) (efforts at harmonization of federal and provincial environmental assessments "an exercise in cooperative federalism"); see also paras. 13 (majority), 84 (dissent) (formal intergovernmental agreement an example of cooperative federalism). 
neither descriptively accurate ${ }^{58}$ nor normatively attractive. ${ }^{59}$ The Supreme Court simply asserts, without explanation, that cooperative federalism ought to be facilitated by the courts.

\section{(d) Predictability (or Incremental Change) in the Division of Powers}

The second idea that figures prominently in Canadian Western Bank, then, is that the Supreme Court, in its division of powers cases, will actively attempt to facilitate intergovernmental dialogue about the exercise of legislative power. But would the Supreme Court tolerate a radical adjustment of legislative power, absent a formal amendment, provided there was intergovernmental agreement about the adjustment? The answer, it would seem, is no. This is where the third idea comes into play, that "a certain degree of predictability with regard to the division of powers between Parliament and the provincial legislatures is essential". 60 This must be read together with the idea that the division of powers must be permitted to change to meet new political and cultural realities, and that a court should adopt a posture of restraint, and defer to the political branches in setting the scope of federal and provincial legislative power. Taken together, the Supreme Court can be understood as saying: that the division of powers must be permitted to change to meet the needs of a changing society; that the political branches must take the lead in determining the pace and the extent of that change; but that there is a limit on the pace and the extent of the change that the Supreme Court will tolerate. The Supreme Court does not articulate this limit, but the implication is that it will not tolerate at least some, particularly dramatic, attempts to upset the existing balance of power.

Taking the three ideas outlined above together, the Supreme Court's theory of judicial review can be summarized as follows. The Supreme Court encourages the political branches to take the lead in defining the

58 See, e.g., D. Brown, "Getting Things Done in the Federation" in Constructive and Cooperative Federalism? (2003) I.I.G.R. 1, at 4, 8 (suggesting that competition is the norm in Canada).

59 See, e.g., Royal Commission on the Economic Union and Development Prospects for Canada, Report (Ottawa, 1985), Supp. Statement by A. Breton, Vol. 3, at 486-526 (advocating for Canada a theory of "competitive federalism"); J. Leclair, "Please, Draw Me a Field of Jurisdiction': Regulating Securities, Securing Federalism", in this volume, at (referring to the "legitimate and fruitful interprovincial competition" that "our federalism" is designed to promote); but see Elezar, "Cooperative Federalism", supra, note 53, at c. 4 (suggesting that cooperative and competitive federalism are not mutually exclusive, because "cooperative" refers to the need of governments to work together, not how governments do so).

60 Canadian Western Bank, supra, note 8, at para. 23. 
federal-provincial division of powers. The Supreme Court limits itself primarily to facilitating intergovernmental dialogue about the division of powers and managing the conflicts that result where the political branches fail to reach agreement, and only secondarily to ensuring that the political branches do not egregiously upset the existing federalprovincial balance of power. This theory of judicial review is reflected in the overall approach to division of powers doctrine described in Canadian Western Bank. In the next section, I describe that approach, and also link it to the theory of judicial review described above.

\section{The Supreme Court's Theory of Federalism at Work}

There are three different ways to attack a legislative measure on division of powers grounds. ${ }^{61}$ The first is to challenge its validity. This is the subject of the first stage of a division of powers analysis. The analysis varies, depending on whether the validity of an entire legislative measure or only part of a legislative measure is challenged. If the validity of an entire legislative measure is challenged, the operative doctrine is the "pith and substance doctrine". The court is first required to identify the essential character (the "pith and substance") of the legislation, and is then required to assign the legislation to a federal or provincial head of legislative power. ${ }^{62}$ If the essential character of the legislation is related to a head of legislative power that has been allocated to the enacting legislature, it is valid ("intra vires"); if not, it is invalid ("ultra vires"). In contrast, if the validity of only part of a legislative measure is challenged, the operative doctrine is the "ancillary doctrine" (or "necessarily incidental doctrine"). ${ }^{63}$ The court is first required to determine whether the

61 Hogg, Constitutional Law of Canada, supra, note 4, at 15.8(a).

62 In identifying the essential character of legislation, both the purpose and the legal and practical effect of the legislation are relevant. The purpose will typically be decisive, but the legal and/or practical effects are also relevant, in shedding light on the purpose of the legislation, and will be decisive where they suggest that the legislation actually has an entirely different purpose.

63 Until recently, the pith and substance doctrine was applied in cases involving a challenge to both an entire legislative measure and only part of a legislative measure. The Supreme Court now applies a different approach where only part of a legislative measure is challenged — the ancillary doctrine. However, it remains unclear how the ancillary doctrine is to be applied; in particular, it is not clear how a court is to determine whether a provision encroaches on the jurisdiction of the other order of government at step 1. In two cases, the Supreme Court seemed to apply the pith and substance doctrine: see Global Securities Corp. v. British Columbia (Securities Commission), [2000] S.C.J. No. 5, [2000] 1 S.C.R. 494, at paras. 19-20 (S.C.C.) [hereinafter "Global Securities Corp.”]; and Kitkatla Band, supra, note 12, at paras. 65-71. However, in a later case, the Supreme Court seemed to apply a different approach: see Kirkbi AG v. Ritvik Holdings Inc., [2005] S.C.J. No. 66, [2005] 3 S.C.R. 302, at paras. 19-27 (S.C.C.) [hereinafter "Kirkbi"]. See also General Motors of 
provision encroaches on the jurisdiction of the other level of government. If not, the provision is intra vires the enacting legislature. But if so, the provision may nonetheless still be intra vires the enacting legislature if: (a) it is part of a valid legislative scheme; and (b) it is sufficiently integrated into that legislative scheme. The final step turns on the seriousness of the encroachment: where the encroachment is minimal, it is sufficient if the provision is "functionally related" to the legislative scheme; but where the encroachment is not minimal, the provision must be "truly necessary" or "integral" to the legislative scheme.

The second way to challenge a legislative measure on division of powers grounds is to challenge its applicability. The operative doctrine here is the doctrine of interjurisdictional immunity. The doctrine of interjurisdictional immunity restricts the extent to which otherwise valid legislation of general application enacted by one order of government can interfere with the "basic core" of any subject that is under the jurisdiction of the other order of government. ${ }^{64}$ Where it applies, the law is not struck down as invalid; rather, the law is valid in most of its applications, but is interpreted in such a manner that it will not apply to the subject matter that is under the jurisdiction of the other order of government. This process is referred to as "reading down".

The third way to challenge a legislative measure on division of powers grounds is to challenge its operability. The operative doctrine here is the paramountcy doctrine. The paramountcy doctrine deals with situations of conflict between otherwise valid, but overlapping, federal and provincial legislation. Where there is a conflict, the federal legislation prevails; the provincial legislation is rendered inoperative; not entirely, but to the extent of the inconsistency between the federal and provincial legislation.

In Canadian Western Bank, after reflecting on "the principle of federalism", the Supreme Court outlined in detail its preferred approach to these doctrines. The theory of judicial review outlined by the Supreme Court is reflected in this doctrinal approach. The Supreme Court acts with restraint, by tolerating significant overlap in federal and provincial

Canada Ltd. v. City National Leasing Ltd., [1989] S.C.J. No. 28, [1989] 1 S.C.R. 641, at 666-69 (S.C.C.) [hereinafter "General Motors"], per Dickson C.J.C.

This has parallels with the U.S. idea of intergovernmental immunity, which limits the ability of the states to regulate federal instrumentalities: see McCulloch v. Maryland, 17 U.S. (4 Wheat.) 316, at 436 (1819) (Maryland state tax on the Bank of the United States unconstitutional). 
legislative power. ${ }^{65}$ It does so by permitting both orders of government to enact legislation that substantially impacts the jurisdiction of the other order of government; by applying the double aspect doctrine to permit both orders of government to regulate a given subject area; and by restricting the application of the doctrine of interjurisdictional immunity. The Supreme Court largely limits itself to managing overlapping federal and provincial legislation to avoid legislative conflict. The key doctrine here is the paramountcy doctrine. However, the Supreme Court restricts its reach, by interpreting overlapping legislation to avoid conflict in operation, if possible, and applying the doctrine in the situations that remain. The operative assumption appears to be that permitting overlap between federal and provincial legislative power will act as an incentive to intergovernmental dialogue about particular exercises of that legislative power. The Supreme Court does not entirely forswear a role in defining the scope of federal and provincial legislative power, but it openly encourages the political branches to take the lead in this regard, indicating that it will be prepared to intervene only where one order of government significantly upsets the existing balance of power.

\section{(a) Validity: The Pith and Substance Doctrine and the Ancillary Doctrine}

The Supreme Court did not discuss the ancillary doctrine in Canadian Western Bank. However, in keeping with its recent decisions, it did outline an approach to the pith and substance doctrine that accommodates significant overlap in jurisdiction.

The approach outlined by the Supreme Court to the problem of extrajurisdictional effects is representative. Under this approach, the essential character of legislation is determinative. Legislation is permitted to have

65 The courts have fluctuated between two different approaches to the division of powers (often in the same period, but in different subject areas). Bruce Ryder refers to these two approaches as the "classical paradigm" and the "modern paradigm": "The Demise and Rise of the Classical Paradigm", supra, note 12. Under the "classical paradigm," the emphasis is placed on exclusivity of legislative power; overlap in federal-provincial legislative power is limited, to the greatest extent possible, and federal-provincial legislative power is relegated to "watertight compartments". Accordingly, if the federal government is entitled to act, the provinces are not, and vice versa. In contrast, under the "modern paradigm", much less emphasis is placed on exclusivity of federal-provincial legislative power; overlap in legislative power is tolerated, even encouraged. Accordingly, permitting one order of government to act does not necessarily preclude the other order of government from acting; rather, in those many areas where overlap is tolerated, it merely supplements the legislative power of the other order of government. The approach set out in Canadian Western Bank is entirely consistent with the modern paradigm. 
"incidental" effects on the jurisdiction of the other order of government, provided its essential character is related to a legislative power that has been allocated to the enacting legislature. "Incidental" is defined broadly to include "effects that may be of significant practical importance". ${ }^{66} \mathrm{~A}$ court working in the classical paradigm would limit the ability of both orders of government to impact the jurisdiction of the other order of government. The Supreme Court not only eschews this approach, it sets out an approach that permits each order of government to impact "significantly" the jurisdiction of the other order of government. The result is to accommodate substantial overlap in federal and provincial jurisdiction.

The approach outlined by the Supreme Court to the problem of overlap in the heads of legislative power is also representative. The heads of legislative power granted to the federal Parliament and the provincial legislatures overlap considerably; as a result, it is often possible to relate a given legislative measure to either a federal or a provincial head of legislative power. The classic example is dangerous driving. Legislative measures directed at dangerous driving seem to relate to both the federal criminal law power (on the basis that they are directed at public safety) and the provincial property and civil rights power (on the basis that they are directed at the regulation of provincial roads). ${ }^{67}$ The response of the classical paradigm to this problem is to "mutually modify" the legislative heads of power: the relevant legislative head of power of one order of government would be interpreted as including jurisdiction over dangerous driving, and the relevant legislative head of power of the other order of government would be interpreted as excluding jurisdiction over dangerous driving. The response of the modern paradigm to this problem is the "double aspect" doctrine: the federal legislative measure would be sustained under the federal criminal law power, as a measure directed at public safety, and the provincial legislative measure would be sustained under the provincial property and civil rights power, as a measure directed at the regulation of provincial roads; the ultimate effect is to assign jurisdiction over dangerous driving to both the federal and provincial governments. ${ }^{68}$ In Canadian Western Bank, the Supreme Court did not mention the mutual modification doctrine, but it did affirm the role of the double aspect doctrine in responding to the problem of overlap in the

66 Canadian Western Bank, supra, note 8, at para. 28 (emphasis added).

67 See P.W. Hogg, "Canada: Privy Council to Supreme Court" in J. Goldsworthy, ed., Interpreting Constitutions (Oxford: Oxford University Press, 2006), at 68; and generally 66-69. This example was cited by the Supreme Court in Canadian Western Bank, supra, note 8, at para. 30.

68 O'Grady v. Sparling, [1960] S.C.J. No. 48, [1960] S.C.R. 804 (S.C.C.). 
heads of legislative power. It noted that "some matters are by their very nature impossible to categorize under a single head of power", and in response, it extolled the virtues of the double aspect doctrine, which, it said, "ensures that the policies of the elected legislators of both levels of government are respected" ${ }^{69}$ As with the pith and substance doctrine, the result is to accommodate significant overlap in federal and provincial jurisdiction. $^{70}$

\section{(b) Applicability: The Doctrine of Interjurisdictional Immunity}

The most significant aspect of the Supreme Court's discussion of doctrine in Canadian Western Bank is its discussion of the doctrine of interjurisdictional immunity. The Supreme Court reformulated its approach to the doctrine in three ways. ${ }^{71}$ First, it raised the threshold to engage the doctrine. The doctrine will now apply only if the "basic, minimum and unassailable" core of a legislative power granted to one order of government would be impaired by a legislature measure enacted by the other level of government. ${ }^{72}$ (Prior to Canadian Western Bank, the threshold was merely affects, not impairs. ${ }^{73}$ ) Second, it held that the doctrine should generally "be reserved for situations already covered by precedent". ${ }^{74}$ Finally, it said that the doctrine should now normally be considered after the federal paramountcy doctrine, at least in "the absence of prior case law favouring its application to the subject matter at hand". 75 (Prior to Canadian Western Bank, the doctrine was usually considered before the paramountcy doctrine.)

69 Canadian Western Bank, supra, note 8, at para. 30.

70 I treat the double aspect doctrine and the pith and substance doctrine as allowing overlap in federal-provincial jurisdiction, but in theory, only the pith and substance doctrine actually impacts on the exclusivity of the two lists of legislative powers. The double aspect doctrine purports to respect the exclusivity of the two lists, by treating only the subject matter of the impugned legislation as concurrent. However, the practical effect is the same - jurisdictional overlap. Both orders of government are permitted to enact legislation dealing with "different" aspects of an issue, as in the dangerous driving example.

${ }_{71}$ As noted, Bastarache J. wrote a concurring opinion, disagreeing with the majority's analysis, but not with its result. Justice Bastarache argued that the doctrine of interjurisdictional immunity should always be considered before the paramountcy doctrine, and that the doctrine of interjurisdictional immunity should be engaged where provincial legislation impacts on the core of a federal power, such that federal legislative authority is "'attacked,' 'hindered,' or 'restrained"”: supra, note 8, at para. 123 .

72 Canadian Western Bank, id., at paras. 35-68.

73 Bell Canada v. Quebec (Commission de santé et de la sécurité du travail du Quebec), [1988] S.C.J. No. 41, [1988] 1 S.C.R. 749 (S.C.C.) [hereinafter "Bell Canada"].

74 Canadian Western Bank, supra, note 8, at para. 77.

75 Id., at paras. 69-78. 
These changes are significant, because the basic concern of the doctrine of interjurisdictional immunity is exclusivity of jurisdiction, and the doctrine as it was framed had the potential to limit significantly the overlap allowed under the pith and substance doctrine. A legislative measure enacted by one order of government was permitted to substantially impact the jurisdiction of the other order of government, provided that, in doing so, it did not affect the core of a legislative power assigned to that other order of government. Following Canadian Western Bank, a legislative measure enacted by one order of government will be permitted to impact substantially the jurisdiction of the other order of government, provided that, in doing so, it does not impair the core of a legislative power assigned to that other order of government. This "leaves more room for the concurrence of federal and provincial jurisdiction". ${ }^{76}$

The Supreme Court offered a number of reasons for this stricter approach to the doctrine of interjurisdictional immunity. The first reason offered is that recent division of powers jurisprudence in Canada has allowed for "a fair amount of interplay and indeed overlap between federal and provincial powers". ${ }^{77}$ This trend, we are told, "finds its principled underpinning" in the belief that courts "should favour, where possible, the ordinary operation of statutes enacted by both levels of government", and "avoid blocking the application of laws which are taken to be enacted in the furtherance of the public interest". ${ }^{78}$ For the Supreme Court, strong reliance on the doctrine of interjurisdictional immunity is inconsistent with this trend in the jurisprudence.

The second reason offered speaks to "the importance of co-operation among government actors to ensure that federalism operates flexibly" ${ }^{79}$ Although the Supreme Court does not attempt to clarify exactly why this is so, it suggests that excessive reliance on the doctrine of interjurisdictional immunity is "inconsistent" with the "flexible federalism" that the Court is attempting to promote in its division of powers decisions. ${ }^{80}$

The third reason offered is the need to ensure certainty in the scope of the division of powers. Excessive reliance on the doctrine of interjurisdictional immunity would, it is suggested, "create serious uncertainty", because the doctrine requires judges to define the core of the legislative powers. This is problematic, because the core often lacks determinate

\footnotetext{
76 Hogg \& Godil, "Narrowing Interjurisdictional Immunity", supra, note 9, at 635.

77 Canadian Western Bank, supra, note 8, at para. 36 (citation omitted).

$78 I d$., at para. 37 (emphasis in original).

$79 \quad$ Id., at para. 42.

$80 \quad$ Id.
} 
scope. The Supreme Court concedes that this problem could be addressed, at least in part, if judges were willing to develop "abstract definitions" of the cores of the legislative powers, but this, it responds, would be inconsistent "with the tradition of Canadian constitutional interpretation, which favours an incremental approach". 81

The fourth reason offered is the need to avoid legal vacuums (the absence of legal regulations in a certain area), which are said to be "not desirable". ${ }^{82}$ Excessive reliance on the doctrine of interjurisdictional immunity risks creating legal vacuums, because laws enacted by one order of government cannot effect the core of the jurisdiction of the other order government, even in the absence of a law enacted by that order of government.

The fifth reason offered is that the doctrine of interjurisdictional immunity has tended to operate asymmetrically, in favour of federal jurisdiction and at the expense of provincial legislation, a practice that runs the risk of unintentionally centralizing legislative power. For the Supreme Court, this would be "incompatible with the flexibility and coordination required by contemporary Canadian federalism"; undesirable as a matter of policy, because "so many laws for the protection of workers, consumers and the environment (for example) are enacted and enforced at the provincial level"; and inconsistent with "the principles of subsidiarity, i.e. that decisions are "best [made] at a level of government that is not only effective, but also closest to the citizens affected"". ${ }^{83}$

The final reason offered is that the doctrine is unnecessary, because it is always open to Parliament to enact legislation in areas that it wishes to regulate that triggers the doctrine of paramountcy, by making it "sufficiently precise to leave those subject to it with no doubt as to the residual or incidental application of provincial legislation". ${ }^{84}$

The idea of intergovernmental cooperation plays a key role in the reasons given for embracing this new approach to the doctrine of interjurisdictional immunity. The Supreme Court says that "cooperation among government actors" is important, because it "ensure[s] that federalism operates flexibly" ${ }^{85}$ It also says that the doctrine of interjurisdictional immunity should be restricted because: it has tended to lead to the centralization of legislative power in the federal Parliament, which "is

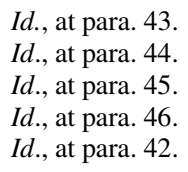


incompatible with the flexibility and co-ordination required by contemporary Canadian federalism"; and a "broad application" is "inconsistent" with the "flexible" cooperative federalism that the Court is attempting to promote. ${ }^{86}$ The Supreme Court does not explain its thinking in any detail. However, its key assumptions appear to be that permitting a fair measure of overlap in federal-provincial legislative power will: ensure that the federal-provincial governments can flexibly work out different allocations of legislative power in different contexts, at different times, as deemed appropriate $;{ }^{87}$ and encourage intergovernmental dialogue about the exercise of those legislative powers in particular regulatory areas. ${ }^{88}$

This assumption, that accommodating overlap in legislative power will encourage intergovernmental dialogue about particular exercises of those legislative powers, requires further exploration. The idea seems counterintuitive. Why would one order of government need to engage in a process of intergovernmental dialogue with the other order of government if it has the legislative power to act? Is it not more likely that it would simply act unilaterally ? $^{89}$ The Supreme Court seems inclined to believe that this will not be the net result. Why might it hold this view? The benefits of overlap in jurisdiction in a federal system have been noted by several federalism scholars in recent years. One benefit that has been claimed is that overlap operates as a kind of democratic safeguard, allowing one order of government to respond to a particular problem where the other order of government fails to act, either effectively or at all. This argument figures in the work of American constitutional scholar Erwin Chemerinsky, who refers to the benefits of "enhancing" and "empowering", not limiting, legislative power. ${ }^{90}$ It also seems to be at work in Canadian Western Bank, in the concern to avoid "leg[islative]

$86 \quad$ Id., at paras. 42,45 .

87 This assumption is shared by others: see e.g., Kramer, "Putting the Politics Back", supra, note 41, at 289 ("the optimal level at which to do things depends on complicated circumstances that change over time. It follows ... that the domain of concurrent legislative jurisdiction must be broad enough to permit authority to be allocated and reallocated").

Again, this assumption is shared by others: see, e.g., D. Weinstock, "Liberty and Overlapping Federalism" in S. Choudhry et al., eds., Dilemmas of Solidarity: Rethinking Distribution in the Canadian Federation (Toronto: University of Toronto Press, 2006), at 171-72 ("When overlap and redundancy are built into the system ... [c] ompromises must be made").

89 Elliot, "Interjurisdictional Immunity", supra, note 9, at 489; and J. Leclair, "Please, Draw Me a Field of Jurisdiction': Regulating Securities, Securing Federalism”, in this volume.

90 E. Chemerinsky, Enhancing Government: Federalism for the 21st Century (Stanford: Stanford University Press, 2008); see also M. Landau, "Redundancy, rationality and the problem of duplication and overlap" (1969) 29(4) Pub. Adm. Rev. 346 (an earlier work making similar arguments). 
vacuums". ${ }^{91}$ However, another benefit ${ }^{92}$ that has been claimed for overlap in jurisdiction is that it can foster cooperation about particular exercises of legislative power. The argument is this: overlap in legislative power inevitably gives rise to situations in which both orders of government wish to provide the same or similar goods and services to the same constituents; this, in turn, gives rise to situations of redundancy, where the involvement of both orders of government may be of no (or even negative) benefit to those constituents; governments, seeking to avoid these situations of redundancy, will be inclined to work together, perhaps due to political forces, or simply a desire to provide public goods and services more efficiently, in an attempt to ensure that this does not occur. $^{93}$ It is unclear whether the Supreme Court has this particular idea in mind, but it does seem clearly to be working from the fundamental assumption that accommodating overlap will indeed operate to "facilitate, not undermine" intergovernmental dialogue.

With these benefits, why not abandon the doctrine of interjurisdictional immunity altogether? The Supreme Court's answer to this question is decidedly subdued: it says that the doctrine is rooted in the text of the Constitution, pointing to various references to "exclusive" legislative power in the text of sections 91 and 92; it also says that the doctrine is rooted in "the principles of federalism", but makes no attempt to expand on this point. ${ }^{94}$ However, although it does not say so explicitly, the answer likely has a good deal to do with the Supreme Court's concern about predictability in the division of powers. Recall the Supreme Court's direction that the doctrine should generally only be applied to protect exclusive jurisdiction in those areas already covered by precedent. This seems an odd limitation to place on a division of powers doctrine. If the doctrine is grounded in the text of the constitution and the principles of federalism, why limit it to situations covered by precedent? However, if predictability is the concern, the limitation makes much more sense: the Supreme Court is worried about significantly upsetting settled expectations about exclusive jurisdiction, so it refrains from

91 Canadian Western Bank, supra, note 8, at para. 44. This argument also reflects an unmistakably pro-government viewpoint: government power is not to be limited, at least not on federalism grounds, but to be empowered, as it is particularly well situated to respond to social/economic problems.

92 This is not seen as a benefit by all: see L.J. O'Toole, "Theoretical development in public administration: Implications for the study of federalism" (1990) 3(4) Governance: An International Journal of Policy Administration 394 (warning that overlap may lead to "endless cycles of bargaining").

93 These themes are explored in more detail in R. Hollander, "Rethinking Overlap and Duplication: Federalism and Environmental Assessment in Australia" (2009) 40(1) Publius 136.

$94 \quad$ Canadian Western Bank, supra, note 8, at para. 33. 
abandoning the doctrine altogether; but it also is not interested in recognizing new areas of exclusive jurisdiction, so it limits the doctrine to situations covered by precedent. The message is clear: change in jurisdiction will be tolerated, but any change must be incremental.

\section{(c) Operability: The Paramountcy Doctrine}

The Supreme Court concluded its discussion of division of powers doctrine in Canadian Western Bank with the paramountcy doctrine. It said that, " $[i] n$ the absence of conflicting enactments of the other level of government", the courts "should avoid blocking the application of measures which are taken to be enacted in furtherance of the public interest". ${ }^{95}$ It then cited this passage from an important article by Paul Weiler:

... the court should refuse to try to protect alleged, but as yet unoccupied, enclaves of governmental power against the intrusions of another representative legislature which has ventured into the area. Instead, the court should try to restrict itself to the lesser but still important role of interpreting statutes of different jurisdictions in the same area, in order to avoid conflict, and applying a doctrine of paramountcy in the few situations which are left. ${ }^{96}$

For the Supreme Court, the paramountcy doctrine is clearly to occupy pride of place in a division of powers analysis. This is not especially surprising. The function of the paramountcy doctrine is to manage overlapping regulation. A court, like the Supreme Court, that is inclined to accommodate overlap in legislative power is likely to downplay the importance of doctrines that privilege exclusivity of legislative power, and to emphasize the importance of doctrines that function to manage any operational conflicts that arise; hence the limits placed on the doctrine of interjurisdictional immunity and the emphasis placed on the paramountcy doctrine. However, the Supreme Court also emphasized that the doctrine should be applied with restraint, because it ultimately operates at the expense of provincial jurisdiction and also reduces legislative overlap.

This call for restraint is evident in the Supreme Court's discussion of the definition of conflict. The Supreme Court affirmed, citing recent precedent, that there are in fact two definitions of conflict: a narrow

$95 \quad$ Id., at para. 37 (emphasis added).

96 Id. (citing P. Weiler, "The Supreme Court and the Law of Canadian Federalism" (1973) 23 U.T.L.J. 307, at 308). 
impossibility of dual compliance test, which applies where it is impossible to comply with both laws; $;{ }^{97}$ and a broader "frustration of federal purpose" test, which applies where the operation of a provincial law would frustrate the purpose of a federal law. ${ }^{98}$ However, it urged courts not to apply the broader "frustration of federal purpose" test too enthusiastically, and cited the following guiding principles: that conflict is not triggered merely by overlapping legislation; that federal and provincial statutes should be construed to avoid conflict, if at all possible; and that an intention should not be imputed to Parliament to "occupy a field" absent "very clear statutory language". 99 Restraint is also evident in the Supreme Court's application of the doctrine to the facts of the case. The federal legislation permitted banks to promote insurance, but prohibited banks from acting "as agent for any person in the placing of insurance"; the provincial legislation required banks to hold a "restricted insurance agent's certificate" in order to promote insurance in the province. There seemed to be an operative conflict. However, the Supreme Court interpreted the definition of "agent" in the federal legislation narrowly, so that it was possible to hold a "restricted insurance agent's certificate" for the purposes of the provincial legislation, without also then being an "agent" (as the provincial certificate seemed to suggest) under the federal legislation.

The theory of judicial review described in Canadian Western Bank is reflected in this doctrinal approach. The Supreme Court acts with restraint, by accommodating overlap in federal and provincial legislative power, and largely limits itself to managing overlapping federalprovincial regulation in order to avoid conflicts in operation. The assumption appears to be that permitting overlap between federal and provincial legislative power will act as an incentive to intergovernmental dialogue about particular exercises of that legislative power. As mentioned above, the Supreme Court does not entirely forswear a role in defining the scope of federal and provincial legislative power, but it openly encourages the political branches to take the lead, indicating that it will be prepared to intervene only where one order of government significantly upsets the existing balance of power.

\footnotetext{
$97 \quad I d$. , at para. 71 (citation omitted).

$98 \quad I d$. , at para. 73.

$99 \quad$ Id., at paras. $72-74$ (citations omitted).
} 


\section{THE DIVISION OF POWERS IN THE MCLACHLIN COURT PRE-CANADIAN WESTERN BANK}

In this section, I discuss the leading pre-Canadian Western Bank division of powers decisions of the McLachlin Court. This discussion serves two related purposes.

The first purpose is to offer a fresh perspective on these decisions. The theory of judicial review described above was not new to Canadian Western Bank. The Supreme Court simply made explicit the theory of judicial review that had quietly been animating its decision-making in division of powers cases for a number of years. I trace the manner in which this theory is reflected in these decisions. In doing so, I augment existing accounts, which tend to emphasize the degree to which the Supreme Court defers to the political branches, but overlook its attempts to facilitate intergovernmental dialogue. ${ }^{100}$

The second purpose is to identify what else can be learned from these decisions about the theory of judicial review described in, and animating, Canadian Western Bank. Although important, the decision in Canadian Western Bank leaves many important questions unanswered. The pre-Canadian Western Bank decisions provide useful answers to some of the questions left open in Canadian Western Bank itself.

\section{Expressions of Intergovernmental Dialogue about Jurisdiction}

The theory of judicial review described in Canadian Western Bank is reflected fairly overtly in those cases where the McLachlin Court was faced with a specific manifestation or expression of intergovernmental dialogue about jurisdiction.

Intergovernmental dialogue has taken three forms in the cases. The first form that it has taken is an intervention, in a constitutional challenge initiated by a private party, in which the order of government that is not before the court supports the constitutionality of the legislation of the order of government that is before the court. ${ }^{101}$ The intergovernmental dialogue here is indirect and after the fact: there is no evidence that the enacting order of government consulted or negotiated with the nonenacting order of government pre-enactment, but the non-enacting order

100 See the sources cited in note 7.

101 The federal and provincial Attorneys General are given notice and intervention rights in all Canadian jurisdictions: see Hogg, Constitutional Law of Canada, supra, note 4, at para. 59.6(a). 
of government intervenes in any event to make the point that it supports the exercise of jurisdiction being challenged. This has occurred with some frequency in division of powers cases before the McLachlin Court. The Supreme Court repeatedly stressed that it will "exercise caution" before finding a legislative measure unconstitutional where this occurs. ${ }^{102}$ The implication seems to be that the Supreme Court will apply two standards of review: a more searching standard of review where there is no intergovernmental agreement about an exercise of jurisdiction, and a less searching standard of review where there is intergovernmental agreement about an exercise of jurisdiction. This is reflected in the outcome of the cases: in not one of the decisions reviewed did the Supreme Court find a constitutional infirmity where there was agreement of this sort about an exercise of jurisdiction.

The second form that intergovernmental dialogue has taken is a legislative measure structured to accommodate interlocking federalprovincial regulation. As with the first example, there is no evidence that the enacting order of government actually consulted or negotiated with the non-enacting order of government pre-enactment, and agreement is expressed in the form of an intervention supporting the legislation at issue. However, unlike with the first example, the legislation is positively structured by the enacting order of government to accommodate complementary regulation.

The Supreme Court considered a legislative measure of this sort in Siemens v. Manitoba (Attorney General). ${ }^{103}$ At issue was the constitutionality of Manitoba legislation ${ }^{104}$ that authorized municipalities to hold

102 Kitkatla Band, supra, note 12, at para. 73 ("the Attorney General of Canada has intervened in support of the view of the British Columbia government with respect to the latter's right to legislate in this area. While this is not determinative ... it does invite the Court to exercise caution before it finds that the impugned provisions of the Act are ultra vires"); see also R. v. Demers, [2004] S.C.J. No. 43, [2004] 2 S.C.R. 489, at para. 28 (S.C.C.); and Rothmans, Benson \& Hedges Inc. v. Saskatchewan, [2005] S.C.J. No. 1, [2005] 1 S.C.R. 188, at para. 26 (S.C.C.) [hereinafter "Rothmans"]. This idea is not new: see Schneider v. British Columbia, [1982] S.C.J. No. 64, [1982] 2 S.C.R. 112, at 138 (S.C.C.), per Dickson J.:

A factor which plays no part in the determination of the constitutional validity of the Act, but which, as a practical matter, is not negligible, is the support of both the provincial and federal authorities for the validity of the legislation. Although it does not resolve the constitutional issue it is interesting to observe that in these proceedings a provincial statute is being attacked on the ground that it falls within federal competence yet the Attorney General of Canada is not contesting the constitutionality of the provincial statute. He would like to see the provincial legislature remain in place;

See also Ontario (Attorney General) v. OPSEU, [1987] S.C.J. No. 48, [1987] 2 S.C.R. 2, at 19-20

(S.C.C.) [hereinafter "OPSEU'], per Dickson C.J.C. (dissenting) (cited in full below).

103 [2002] S.C.J. No. 69, [2003] 1 S.C.R. 6 (S.C.C.) [hereinafter "Siemens"].

104 The Gaming Control Local Option (VLT) Act, S.M. 1999, c. 44. 
a plebiscite to ban video lottery terminals from the municipality. If such a plebiscite was held, and the majority of electors voted to ban video lottery terminals, an automatic prohibition of video lottery gaming in the municipality was triggered. Siemens challenged the provincial legislation, arguing (among other things) that it encroached on the federal government's jurisdiction over criminal law (section 91(24)). The Supreme Court, per Major J., held that the legislation was a valid exercise of the provincial power over property and civil rights (section 92(13)) and matters of a local nature in the province (section 92(16)). In support, Major J. noted that the federal government had intervened in support of the legislation. Justice Major said that "governments, in the absence of jurisdiction, cannot by simple agreement lend legitimacy to a claim that legislation is intra vires", but that, "given that both federal and provincial governments guard their legislative powers carefully, when they do agree to shared jurisdiction, that fact should be given careful consideration by the courts". ${ }^{105}$ This was the familiar call for deference seen in other cases. But Major J. then added an additional gloss. He noted that the federal Criminal Code ${ }^{106}$ specifically established an exception to the gaming and betting offences where a lottery scheme has been established by a province. The legislative record suggested that this was included to allow each province to determine whether it wished to establish a provincial lottery scheme. Justice Major suggested that deference was particularly appropriate where the federal government "has intentionally designed a structure ... that ... promotes federal-provincial cooperation". ${ }^{107}$

The third form that intergovernmental dialogue has taken is interlocking legislation actually resulting from direct negotiation and consultation. ${ }^{108}$ This form of intergovernmental dialogue is unique, because here, there is actually evidence that the two orders of government worked together to establish complementary regulation.

The Supreme Court considered a legislative measure of this sort in Fédération des producteurs de volailles du Québec v. Pelland. ${ }^{109}$ At issue

105 Siemens, supra, note 103 , at para. 34.

106 R.S.C. 1985 , c. C-46, s. 207 (rep. \& sub. c. 52 (1st Supp.), s. 3).

107 Siemens, supra, note 103, at para. 35.

108 For prior comments from the Supreme Court on federal-provincial cooperative schemes, see Coughlin v. Ontario (Highway Transport Board), [1968] S.C.J. No. 38, [1968] S.C.R. 569, at 576 (S.C.C.), per Cartwright J.; Reference re Agricultural Products Marketing Act 1970, [1978] S.C.J. No. 58, [1978] 2 S.C.R. 1198, at 1296 (S.C.C.) [hereinafter "Re Agricultural Products"], per Pigeon J. These cases are discussed in G. Tremblay, "The Supreme Court of Canada: Final Arbiter of Political Disputes" in I. Bernier et al., eds., The Supreme Court of Canada as an Instrument of Political Change (Toronto: University of Toronto Press, 1986), at 194.

109 [2005] S.C.J. No. 19, [2005] 1 S.C.R. 292 (S.C.C.) [hereinafter "Pelland"]. 
in Pelland was the constitutionality of a federal-provincial chicken marketing scheme crafted cooperatively by the federal and provincial governments. Under the scheme, a federal marketing agency (operating under authority granted to it by federal legislation) set a national chicken quota for each province, and a provincial marketing agency (operating under authority granted to it by provincial legislation) divided the quota up between individual producers in that province, making sure that it did not exceed the quota set by the federal marketing agency. Neither the quota set by the federal marketing agency nor the quota set by the provincial marketing agency distinguished between chickens destined for the interprovincial market and chickens destined for the intraprovincial market. As a result, producers were free to market their chickens interprovincially and/or intraprovincially. Pelland, a chicken producer in the Province of Quebec, challenged the provincial legislation in Quebec authorizing the provincial marketing agency to set the individual quotas, on the basis that it related to interprovincial trade, a matter falling within federal jurisdiction, under the federal trade and commerce power (section 91(2)). The provincial legislation did seem to authorize the provinces to set quotas that would, in some cases, relate to chickens sold only outside the province. This would typically have been unconstitutional, but did the cooperative nature of the scheme make a difference? Justice Abella, writing for the Supreme Court, seemed to indicate that it did. She said that it was open to the provinces to regulate the marketing of chickens without regard to destination, at least within the context of a federalprovincial marketing scheme. Why? Because the legislation was devoted to the "organization of the production and marketing of chicken within Quebec and [the] control [of] chicken production to fulfill provincial commitments under a cooperative federal-provincial agreement". ${ }^{110}$ The desire to accommodate a scheme resulting from federal-provincial cooperation is striking; indeed, the decision seems to imply that provincial legislation enacted in order to satisfy provincial commitments under a federal-provincial agreement is, for that reason alone, constitutional. Justice Abella praised the federal-provincial scheme as a "reflection" and "reification" of "Canadian federalism's constitutional creativity and cooperative flexibility", and practically rejoiced that she could identify "no

$110 \quad$ Id., at para. 37 (emphasis added). 
principled basis for disentangling what has proven to be a successful federal-provincial merger". ${ }^{111}$

The theory of judicial review described in Canadian Western Bank is evident in these decisions. As in Canadian Western Bank, the Supreme Court did not completely eschew a role in defining the division of powers. The Supreme Court said, repeatedly, that intergovernmental dialogue is not determinative of constitutionality. The clear implication is that the Supreme Court believes that it still has a role to play in division of powers cases, even in the face of intergovernmental agreement about jurisdiction.

However, as in Canadian Western Bank, the Supreme Court is content to let the political branches take the lead in setting the balance of power. This is particularly true where the political branches agree about an exercise of jurisdiction in a particular regulatory area. The Supreme Court is reluctant to intervene, because this would involve the Supreme Court substituting its vision of the ideal federal-provincial balance of power for the vision of the political branches. This would be inappropriate, because division of powers cases engage political notions, and accordingly, ought to be left to politics. ${ }^{112}$

Finally, as in Canadian Western Bank, while the Supreme Court is not anxious to play a major role in setting the balance of power, it is plainly concerned to facilitate intergovernmental dialogue about the balance of power. The Supreme Court consistently deferred to expressions of intergovernmental dialogue about exercises of jurisdiction in particular regulatory areas. This encourages, or provides an incentive to, future intergovernmental dialogue. In that sense, the Supreme Court is simultaneously adopting a passive role (deferring to past expressions of intergovernmental dialogue about jurisdiction) and an active role (encouraging future intergovernmental dialogue). ${ }^{113}$

These decisions also provide more insight into what intergovernmental dialogue (or "cooperative federalism") actually means to the Supreme

111 Id., at paras. 15, 38. For a similar comment in a similar context, see Re Agricultural Products, supra, note 108, at 1296, per Pigeon J. ("when after 40 years a sincere cooperative effort has been accomplished, it would be really unfortunate if it was all brought to nought. While I adhere to the view that provinces may not make use of their control over local undertakings to affect extraprovincial marketing, this does not, in my view, prevent the use of provincial control to complement federal regulation of extraprovincial trade") (emphasis added).

112 Employment Insurance Reference, supra, note 44, at para. 10.

113 For a particularly strong call for future intergovernmental dialogue regarding national class actions, see Canada Post Corp. v. Lépine, [2009] S.C.J. No. 16, [2009] 1 S.C.R. 549, at paras. 56-57 (S.C.C.). 
Court. In short, it appears to mean, simply, agreement about an exercise of jurisdiction. The Supreme Court may prefer a model of intergovernmental dialogue in which the federal and provincial governments actually engage in a direct form of negotiation and consultation, particularly where a legislative proposal has important implications for the other order of government; it heaped praise on just such a scheme in Pelland. However, in the vast majority of the cases, intergovernmental dialogue took a different form. It took the form of an indirect, organic process of action and response, with legislative power exercised unilaterally, and the exercise of jurisdiction agreed to by the other level of government after the fact, in a court challenge. The Supreme Court seemed equally prepared to accept this form of intergovernmental dialogue, suggesting that agreement is paramount.

\section{Accommodating Overlap, Managing Conflict: Pre-Canadian Western Bank}

The theory of judicial review described in Canadian Western Bank is also reflected, albeit less overtly, in the McLachlin Court's overall approach to decision-making in earlier division of powers cases. I discuss how in the section that follows.

\section{(a) Accommodating Overlap: The Pith and Substance Doctrine}

One of the core aspects of the theory of judicial review described in Canadian Western Bank is deference to the political branches. This posture of deference is reflected in the Supreme Court's discussion of the pith and substance doctrine. Little attempt is made to place strict limits on federal or provincial legislative power. Rather, the Supreme Court articulates an approach to the pith and substance doctrine that accommodates significant overlap in jurisdiction, leaving it to the political branches to determine how legislative power will actually be exercised in particular regulatory areas.

The McLachlin Court consistently adopted a similar approach to the pith and substance doctrine in its pre-Canadian Western Bank division of powers decisions. It did so in two ways later discussed in Canadian Western Bank: by permitting both orders of government to enact legislation that substantially impacts the jurisdiction of the other order of government, and by allowing both orders of government to regulate a 
particular area of mutual concern, under the "double aspect" doctrine. But it also did so in one important way not later discussed in Canadian Western Bank: by giving a generous reading to particular heads of legislative power, by eschewing evidence of original intent.

\section{(i) Challenges to the Validity of Federal Legislation}

The first two methods of accommodating overlap in jurisdiction are evident in the Supreme Court's decision in the Firearms Reference. ${ }^{114}$ At issue in that case were the provisions in the federal government's gun control legislation ${ }^{115}$ requiring owners to register, and obtain a licence to own, "ordinary firearms" (for example, hunting rifles). The gun control law was (and still is) controversial. The Government of Alberta, representing a constituency that is hostile to gun control, referred the law to the Alberta Court of Appeal for an "advisory opinion"" on its constitutionality. Alberta argued that the law was ultra vires the federal government, on the basis that it fell within the scope of the provincial power over property and civil rights (section 92(13)). The federal government defended the law, arguing that it was intra vires the federal government, on the basis that it fell within the scope of its criminal law power (section 91(27)) and/or its general residuary power to legislate for the "Peace, Order and Good Government" of Canada (section 91).

It is well established that a federal law must satisfy three criteria in order to be valid as an exercise of the federal criminal law power: the federal law must prohibit certain activity; the prohibition must be backed by a penalty; and the prohibition/penalty must have a valid criminal law purpose. ${ }^{117}$ The majority (3-2) of the Alberta Court of Appeal held that

114 Reference re Firearms Act (Can.), [2000] S.C.J. No. 31, [2000] 1 S.C.R. 783 (S.C.C.) [hereinafter "Firearms Reference"].

115 Firearms Act, S.C. 1995 , c. 39, amending the Criminal Code, R.S.C. 1985, c. C-46.

116 The Supreme Court of Canada and the provincial appellate courts have the jurisdiction, by statute, to provide advisory opinions on legal questions referred to them by the federal and provincial governments. Legal questions from the federal government are referred directly to the Supreme Court; legal questions from provincial governments are referred to the relevant provincial appellate court, but can be appealed to the Supreme Court. An advisory opinion is not binding, strictly speaking, but it is usually treated as binding in practice. See Hogg, Constitutional Law of Canada, supra, note 4, at 8.6.

${ }_{117}$ Reference re Dairy Industry Act (Can.), S. 5(a), [1948] S.C.J. No. 42, [1949] S.C.R. 1, at 49 (S.C.C.), per Rand J. Justice Rand's reasons were adopted on appeal by the Privy Council: [1950] J.C.J. No. 1, [1951] A.C. 179 (P.C.). 
the federal gun control law satisfied these three requirements. ${ }^{118}$ The federal law contained a prohibition (both unregistered firearms and unlicensed ownership of firearms); this prohibition was backed by a penalty (violation of either prohibition was punishable as a summary conviction offence); and the prohibition/penalty had a valid criminal law purpose (enhancing public safety by controlling access to dangerous firearms). Alberta appealed to the Supreme Court. The Supreme Court, writing per curiam, agreed with the majority of the Court of Appeal and denied the appeal.

Alberta raised a number of concerns about the federal law before the Supreme Court, but one of the primary concerns that it raised was that the law inappropriately trenched on provincial jurisdiction, and in so doing, dramatically upset the balance of power. The Supreme Court agreed that it was important to take account of the balance of power in deciding the case, but said that it would intervene to protect that balance only where the provincial effects of a federal law were so substantial that it was clear that the law was actually in "pith and substance" directed to a matter falling within provincial jurisdiction (or vice versa). The federal gun control law did not upset the balance of power in this manner; on the contrary, its extrajurisdictional effects were merely incidental. The most significant extrajurisdictional effect of the law was that it would eliminate the ability of provinces like Alberta not to regulate ordinary firearms at all. However, this was not a problem, because "overlap of legislation [was] to be expected and accommodated in a federal state", ${ }^{119}$ and the double aspect doctrine "permit[ted] both levels of government to legislate in one jurisdictional field for two different purposes". ${ }^{20}$

In reaching this result, the Supreme Court was untroubled that the law regulated a particular type of property. "Exercises of the criminal law power often", it said, "affect property ..., as many aspects of the criminal law deal with property and its ownership." 21 What mattered was the purpose of the law, and here, the law was aimed directly at enhancing public safety, and only indirectly at regulating property. The Supreme Court was also untroubled that the law created a complex regulatory regime enabling a federal official (the chief firearms officer) to regulate a particular type of property. The answer was the Supreme Court's decision

118 Reference re Firearms Act (Can.), [1998] A.J. No. 1028, 164 D.L.R. (4th) 513, 65 Alta. L.R. (3d) 1 (Alta. C.A.).

119 Firearms Reference, supra, note 114, at para. 26.

$120 \quad I d$. , at para. 52.

$121 \quad I d$., at para. 50. 
in R. v. Hydro-Québec. ${ }^{122}$ In that case, a five-judge majority of the Supreme Court upheld a federal law ${ }^{123}$ that established a complex scheme for the regulation of toxic substances. Unlike that law, the prohibitions in this law were not defined by an administrative body, but stated clearly in the legislation; moreover, the discretion granted to the chief firearms officer was constrained by the legislation itself. If the law in Hydro-Québec was valid, this law was certainly valid as well. Finally, the Supreme Court was also untroubled that the legislation did not outright prohibit, but merely regulated, ordinary firearms. The answer was the Supreme Court's decision in RJR-MacDonald v. Canada (Attorney General). ${ }^{124} \mathrm{In}$ that case, a seven-judge majority of the Supreme Court upheld a federal law ${ }^{125}$ prohibiting (with exceptions) the advertising and promotion, but not sale, of tobacco products under the criminal law power. Parliament was free here, as there, to regulate indirectly under its criminal law power.

This decision contains the hallmarks of the approach later outlined in Canadian Western Bank. The Supreme Court upheld a law that has a substantial impact on provincial jurisdiction over property, and dismissed as incidental the effects that the legislation has on provincial jurisdiction. It also rejected the claim that it ought to protect the ability of the provinces to leave particular jurisdictional fields unregulated, in whole or in part; the answer to this claim was the double aspect doctrine, which permits both orders of government to regulate "different" aspects of a particular issue. $^{126}$

122 [1997] S.C.J. No. 76, [1997] 3 S.C.R. 213 (S.C.C.) [hereinafter "Hydro-Québec"]. Justice La Forest wrote for the majority, L'Heureux-Dubé, Gonthier, Cory and McLachlin JJ. concurring; Lamer C.J.C. and Iacobucci J. dissented, with Major and Sopinka JJ. concurring.

123 Canadian Environmental Protection Act, R.S.C. 1985, c. 16 (4th Supp.).

124 [1995] S.C.J. No. 68, [1995] 3 S.C.R. 199 (S.C.C.) [hereinafter "RJR-MacDonald"]. The law was challenged on division of powers and Charter grounds. The division of powers challenge was rejected, but the Charter challenge was successful. Justice La Forest wrote the lead judgment on the division of powers issue, with the support of Lamer C.J.C. and L'Heureux-Dubé, Gonthier, Cory, Iacobucci and McLachlin JJ.; Major J. dissented, with Sopinka J. concurring.

125 Tobacco Products Control Act, S.C. 1988, c. 20.

126 See also Reference re Same-Sex Marriage, [2004] S.C.J. No. 75, [2004] 3 S.C.R. 698, at para. 32 (S.C.C.) [hereinafter "Same-Sex Marriage Reference"] (federal legislation recognizing same-sex marriage upheld, notwithstanding that it would affect provincial jurisdiction, by requiring the provinces to issue marriage licences, register marriages, provide civil solemnization services to same-sex couples, and make available a "host of legal incidents attendant upon marital status"; these effects were incidental, and thus irrelevant); and Employment Insurance Reference, supra, note 44 (federal legislation granting maternity and paternity benefits to mothers and parents respectively upheld, even though the legislation had the effect of allowing mothers and parents to take time off; because the provisions did not actually grant the legal right to take maternity or paternity leave, but 
The third method of accommodating overlap in jurisdiction - interpreting federal heads of legislative power generously, by eschewing original intent - is clearly evident in two decisions. ${ }^{127}$ The first is the decision of the Supreme Court in the Same-Sex Marriage Reference. ${ }^{128}$ Legislative jurisdiction in Canada relating to marriage is divided between the federal and provincial governments. The federal government is given jurisdiction over "marriage and divorce" (section 91(26)) and the provincial governments are given jurisdiction over "the solemnization of marriage" (section 92(12)). According to judicial interpretation, section 91(26) confers on the federal government legislative competence to regulate the legal capacity to marry (essential validity), whereas section 92(12) confers on the provincial governments legislative competence to regulate the formal ceremonial or evidentiary requirements of marriage (formal validity). ${ }^{129}$ In 2003-2004, the federal government drafted legislation, to have effect across the country, reformulating the different-sex definition of marriage to include same-sex couples. ${ }^{130}$ Anticipating a constitutional challenge from several provinces, the federal government then referred the proposed legislation to the Supreme Court, asking it to consider whether it fell within the legislative authority of the federal government over "marriage and divorce". ${ }^{131}$

The Supreme Court, writing per curiam, concluded that the federal government did indeed have the legislative authority to change the definition of marriage. ${ }^{132}$ The Supreme Court rejected the argument that the

only replacement income, if maternity or paternity leave were otherwise available under provincial legislation or employment contract, these effects as well were incidental, and thus irrelevant).

127 See also Ward v. Canada (Attorney General), [2002] S.C.J. No. 21, [2002] 1 S.C.R. 569 (S.C.C.) (broadly interpreting the federal power over fisheries (s. 91(12)), and rejecting a narrower interpretation offered by the Newfoundland Court of Appeal).

128 Same-Sex Marriage Reference, supra, note 126.

129 Reference re Marriage Act (Can.), [1912] S.C.J. No. 10, 46 S.C.R. 132 (S.C.C.).

130 The complete story is told in W.K. Wright, "The Tide in Favour of Equality: Same-Sex Marriage in Canada and England and Wales" (2006) 20 Int. J. Law, Pol. \& Family 249, at 251-58.

131 The Supreme Court was also asked to consider whether: (a) s. 1 of the proposed legislation, redefining marriage, was consistent with the Charter; (b) whether freedom of religion protects religious officials from being compelled to perform a same-sex marriage; and (a question added later) (c) whether the opposite-sex definition of marriage violated the Charter.

132 In an attempt to allay the concerns of religious officials opposed to same-sex marriage, the legislation also provided that "[n]othing in this Act affects the freedom of officials of religious groups to refuse to perform marriages that are not in accordance with their religious beliefs" (s. 2). The Supreme Court held that s. 2 was ultra vires the federal government because it legislated an exemption to existing solemnization requirements. The Supreme Court rejected the argument of the federal government that the provision served merely to make it clear that the federal government wanted the legislation to be read consistently with the division of powers; this, the Supreme Court said, was a matter for the courts. 
meaning of "marriage" was constitutionally fixed, necessarily incorporating a different-sex requirement. This, it said, was "frozen concepts" reasoning that ran "contrary to one of the most fundamental principles of Canadian constitutional interpretation: that our Constitution is a living tree which, by way of progressive interpretation, accommodates and addresses the realities of modern life". ${ }^{133}$ The different-sex definition of marriage "spoke to a society of shared social values where marriage and religion were thought to be inseparable", but Canada was now a pluralistic society, and what was "natural" to marriage was contested. ${ }^{134}$ It could not be said that "marriage' ... read expansively ... excludes samesex marriage". 135

This is a striking example of a generous reading of a federal head of power. Applying a presumption of constitutionality, the Supreme Court placed the burden on those arguing against the legislation to demonstrate that the term "marriage", read generously, could not include same-sex marriage. Evidence that "marriage" in 1867 would have been understood to include only different-sex marriage was insufficient. The heads of power must, it said, be given a generous interpretation, so that the "Constitution succeeds in its ambitious enterprise, that of structuring the exercise of power by the organs of the state in times vastly different from those in which it was crafted". ${ }^{136}$

The broad reading of federal legislative power evident in the SameSex Marriage Reference was also prominently on display in the Employment Insurance Reference. ${ }^{137}$ At issue were the provisions in the federal Employment Insurance Act ${ }^{138}$ relating to maternity leave and parental leave benefits for eligible employees. The provisions granted maternity benefits to women who were absent from work by reason of pregnancy and parental benefits to parents who were absent from work in order to care for a newborn child. In 2001, the government of Quebec announced its own maternity leave and parental leave benefit program, and initiated a constitutional challenge to the federal program, by asking the Quebec Court of Appeal, on a reference, to consider whether the provisions in the federal legislation were ultra vires the federal government. ${ }^{139}$ Quebec

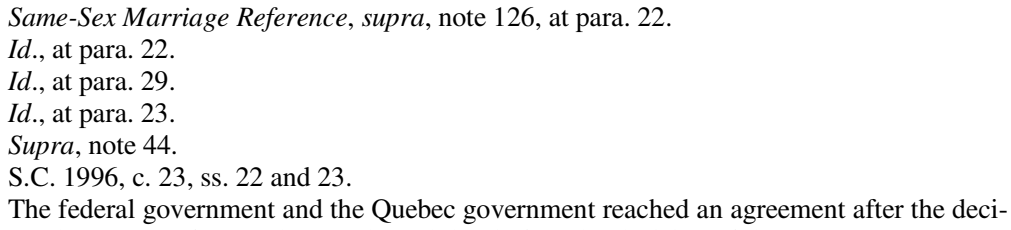

The federal government and the Quebec government reached an agreement after the decision of the Quebec Court of Appeal was released, but before the decision of the Supreme Court was 
argued that the maternity leave and parental leave benefits were really social assistance measures that fell within provincial competence under section 92(13), the provincial power over property and civil rights. The federal government responded that the maternity leave and parental leave benefits were really temporary income support measures, and that it was open to it to enact such measures under section 91(2A), the federal power over unemployment insurance. The Quebec Court of Appeal agreed with Quebec and struck down the provisions. ${ }^{140}$ The Supreme Court, however, agreed with the federal government, and allowed the appeal, upholding the provisions under section $91(2 \mathrm{~A}) .{ }^{141}$

Both courts adopted a radically different approach. The Court of Appeal adopted an original intent approach, focusing on whether the provision of maternity leave and parental leave benefits by the federal government was consistent with the bargain struck by the federal and provincial governments in 1940, when the Constitution Act, 1867 was amended to grant the federal government jurisdiction over unemployment insurance. ${ }^{142}$ It began by noting that welfare and social security measures typically come under provincial jurisdiction. It then proceeded to analyze a number of period documents, to determine whether, in amending the division of powers, the federal and provincial governments intended to subtract jurisdiction over maternity and parental leave benefits from provincial jurisdiction, by giving that jurisdiction to the federal government. It concluded that no such intent was evident. On the contrary, these documents demonstrated conclusively that "the amendment was aimed at enabling federal authorities to set up a plan to insure individuals against lost income following the loss of their job for economic reasons, not following the interruption of their employment for personal reasons". ${ }^{143}$ Applying this reading, the conclusion was obvious. The

released. The federal government agreed to exempt the Province of Quebec from the federal parental leave benefits scheme. It amended the federal legislation, providing that federal parental leave benefits would be reduced or eliminated where "benefits are payable to a claimant ... for the same reasons under a provincial law...". Employment Insurance Act, S.C. 1996, c. 23, s. 23, as am. by S.C. 2005 , c. 30 , s. 130 . The federal legislation already contained a similar provision relating to provincial maternity leave: s. 22(3).

140 Quebec (Attorney General) v. Canada (Attorney General), [2004] J.Q. no 277, 245 D.L.R. (4th) 515 (Que. C.A.) [hereinafter "Employment Insurance Reference (C.A.)"].

141 Employment Insurance Reference, supra, note 44.

142 This head of power was added by constitutional amendment in 1940, after the first federal statute establishing an unemployment insurance regime was declared unconstitutional, on the basis that unemployment insurance was a matter of "property and civil rights in the province", and therefore within provincial competence: see Reference re Employment and Social Insurance Act (Can.), [1937] J.C.J. No. 6, [1937] A.C. 355 (P.C.).

${ }_{143}$ Employment Insurance Reference (C.A.), supra, note 140, at para. 72. 
benefits conferred were "not paid further to the loss of a job for economic reasons; rather, they [were] paid further to the interruption of an individual's employment because of a personal inability to work". ${ }^{144}$ Accordingly, the provisions conferring these benefits were invalid.

Allowing the appeal, the Supreme Court, per Deschamps J., adopted a "living tree" approach, and strongly criticized the Court of Appeal for its "original intent approach to interpreting the Constitution". ${ }^{45}$ While evidence as to original intent was relevant, it was not to be treated as conclusive. The Supreme Court also implicitly criticized the Court of Appeal for adopting a mutual modification approach to the heads of legislative power. "[W]here a specific power has been detached from a more general head of power, the specific power cannot be evaluated in relation to the general power, because any evolution would then be regarded as an encroachment." The proper approach was to "consider the essential elements of the power and to ascertain whether the impugned measure [was] consistent with the natural evolution of that power". ${ }^{146}$

Applying this approach, the Supreme Court held that the purpose (the "pith and substance") of the impugned provisions was to provide replacement income to pregnant women (maternity leave) and parents (parental leave) when their employment was interrupted by a decision to take maternity leave or parental leave, not the actual provision of maternity leave or parental leave itself; and that this fell within the scope of the federal unemployment insurance power. That power was not limited, as suggested by the Court of Appeal, to legislation dealing with involuntary unemployment. A court must take "a progressive approach to ensure that Confederation can be adapted to new social realities". ${ }^{147}$ In this case, those new social realities included "the evolution of the role of women in the labour market and the role of fathers in child care". ${ }^{148}$ The federal legislative power over unemployment insurance extended to legislation aimed, as here, at maintaining economic security, by paying temporary income replacement benefits in the event of an interruption of employment, whether voluntary or involuntary. ${ }^{149}$

This is another striking example of the generous reading of a federal head of power. In 1940, when the amendment was drafted, maternity and

\footnotetext{
$144 \quad I d$., at para. 75.

145 Employment Insurance Reference, supra, note 44, at para. 9.

$146 \quad I d$. , at para. 44.

$147 \quad I d$. , at para. 9.

$148 \quad$ Id., at para. 77.

$149 I d$., at paras. $48,62$.
} 
paternity leave benefits were not contemplated. The prevailing assumptions at that time were that women would not work after marriage, and that they would take on primary childcare responsibilities. However, the social reality had changed, and so too, said the Supreme Court, should the scope of the federal government's legislative jurisdiction. The result is that both the federal and provincial governments now have the authority to enact legislation dealing with maternity and parental leave benefits. The Supreme Court was predictably comfortable with this result. "It is rare," it said, "that all the subjects dealt with in a statute fall entirely under a single head of power." Moreover, "[t]he power of one level of government to legislate in relation to one aspect of a matter takes nothing away from the power of the other level to control another aspect within its own jurisdiction." 150

\section{(ii) Challenges to the Validity of Provincial Legislation}

These cases are typical of the manner in which the McLachlin Court applied the pith and substance doctrine where the validity of federal legislation was at issue: overlap in jurisdiction was accommodated, not eschewed. The McLachlin Court adopted a similar approach to the pith and substance doctrine where the issue was the validity of provincial legislation. ${ }^{151}$ However, it did not do so by offering a broader reading of provincial heads of legislative power, as it did in the Same-Sex Marriage Reference and the Employment Insurance Reference with federal legislation. This is unsurprising. The vast majority of the McLachlin Court's division of powers cases have turned on the interaction between one or more of the federal heads of legislative power and the provincial

$150 \quad$ Id., at para. 8. See also Confédération des syndicats nationaux v. Canada (Attorney General), [2008] S.C.J. No. 69, [2008] 3 S.C.R. 511 (S.C.C.) [hereinafter "Confédération des syndicats"] (embracing an even broader reading of the federal unemployment insurance power).

${ }_{151}$ Bruce Ryder, writing before Canadian Western Bank, suggested that the Supreme Court is particularly concerned to permit the growth of federal legislative power: "The End of Umpire?", supra, note 7, at 351. If the implication is that the Supreme Court has not expanded the scope of provincial heads of power, I agree; but if the implication is that the Supreme Court is not also concerned to give a generous scope to provincial legislative power, I do not agree. The current Supreme Court seems inclined to give a broad scope to federal and provincial legislative power. (Strong evidence of this can be found in the Supreme Court's recent decision in Consolidated Fastfrate Inc. $v$. Western Canada Council of Teamsters, [2009] S.C.J. No. 53, [2009] 3 S.C.R. 407 (S.C.C.) [hereinafter "Consolidated Fastfrate"].) However, because the provincial power over property and civil rights was already interpreted broadly, it had no need to do so by expanding its reading of provincial heads of legislative power. I reserve judgment in this paper about the impact that the Supreme Court's generous approach to federal legislative power is likely to have, in practice, on provincial jurisdiction. 
legislative power over property and civil rights. The provincial legislative power over property and civil rights had already been interpreted broadly by the courts. Where the issue was the validity of provincial legislation, the McLachlin Court accommodated overlap in jurisdiction by permitting the provincial legislatures to enact legislation that substantially impacts federal jurisdiction, and/or by allowing both orders of government to regulate in particular areas, under the double aspect doctrine.

The decision of the Supreme Court in Global Securities Corp. v. British Columbia (Securities Commission) is typical. ${ }^{152}$ At issue was a provision in British Columbia's Securities Act ${ }^{153}$ that authorized the British Columbia Securities Commission to order registered brokers in the province to produce records "to assist in the administration of the securities laws of another jurisdiction". ${ }^{154}$ The respondent challenged the provision, on the basis that its pith and substance was the enforcement of the securities laws of another jurisdiction, a matter falling within federal jurisdiction.

The Supreme Court, per Iacobucci J., rejected the challenge, holding that the provision fell within provincial jurisdiction. The essential character of the provision was the enforcement of British Columbia's securities laws, not the enforcement of the securities laws of another jurisdiction, for two reasons. First, in order to enforce British Columbia's securities laws, the Commission would require access to records held outside the province. Justice Iacobucci emphasized the "indispensable" need for interjurisdictional cooperation among securities regulators, and said that this would be forthcoming only if the Commission reciprocated. ${ }^{155}$ Second, the Commission had an interest in facilitating the investigation of possible wrongdoing outside of the province by a British Columbia registered broker, because this would be relevant to the fitness of that broker to continue trading in the province. The Commission could, of course, conduct its own investigation, but it could also "choose to have that task carried out by a foreign regulator, which is presumably in a better position to conduct such an investigation". ${ }^{156}$ Justice Iacobucci had little difficulty with the next stage of the analysis; it had long been established that securities regulation fell within provincial jurisdiction, as a matter of

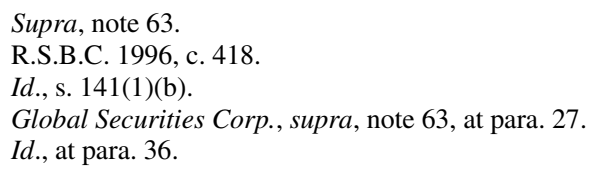


property and civil rights in the province (section 92(13)). Significantly, Iacobucci J. did not disagree that the provision had extraprovincial effects; it did, after all, permit the Commission to order the production of records located in the province, which could then be used in an extraprovincial investigation. However, these effects were said to be "clearly incidental" to the dominant purpose of the provision - intraprovincial enforcement. ${ }^{157}$

The decision of the Supreme Court in Krieger v. Law Society of Alberta $^{158}$ is to similar effect. As in all provinces, the Alberta government delegated its power to regulate the legal profession to a provincial regulatory body, the Law Society of Alberta. ${ }^{159}$ The Law Society enacted rules of professional conduct for lawyers practising law in that province. One rule, specifically addressed to Crown attorneys in the province, required "timely disclosure" to defence counsel "of all known relevant facts and witnesses, whether tending towards guilt or innocence". ${ }^{160}$ This rule was accompanied by commentary, explaining that it would apply only where there was an allegation of dishonesty or bad faith. ${ }^{161}$ At issue was whether this rule was intra vires the province. Krieger, a Crown attorney in Alberta who was alleged to have violated the rule, argued that the answer was no. The purpose of the rule, he said, was to regulate Crown disclosure during the course of a prosecution, by establishing more onerous obligations to disclose information than exists at law; accordingly, it fell within the scope of the federal power over criminal law and criminal procedure, section 91(27). The Law Society of Alberta, however, argued that the purpose of the rule was to establish an ethical standard; accordingly, it fell within the scope of the provincial power in relation to property and civil rights (section 92(13)) or the administration of civil and criminal justice (section 92(14)).

The Supreme Court, in an opinion written jointly by Iacobucci and Major JJ., held that the rule fell within the scope of the provincial power in relation to property and civil rights in the province under section 92(13). Justices Iacobucci and Major noted that there was "a strong possibility of overlap between the provincial and federal spheres", because the federal government was granted jurisdiction over criminal law and

\footnotetext{
$157 \quad I d$. , at paras. 37-38.

158 [2002] S.C.J. No. 45, [2002] 3 S.C.R. 372 (S.C.C.) [hereinafter "Krieger"].

159 Legal Profession Act, S.A. 1990, c. L-9.1 (now R.S.A. 2000, c. L-8).

160 Crown disclosure is constitutionally required: $R$. v. Stinchcombe, [1991] S.C.J. No. 83, [1991] 3 S.C.R. 326 (S.C.C.) [hereinafter "Stinchcombe"].

${ }_{161}$ Alberta Code of Professional Conduct, Rule 28(d).
} 
criminal procedure under section 91(27), which includes the authority to determine the procedures that govern criminal trials, and the provincial governments were granted jurisdiction to license and regulate lawyers under section 92(13), which includes the authority to deal with breaches of ethics. ${ }^{162}$ However, the rule was valid, because it was situated in the provincial rules of professional conduct; it was authorized by the relevant delegating legislation; it was limited to dishonest or bad faith breaches; and the commentary indicated that it was not intended to establish more onerous disclosure obligations than already existed at law. The result is more overlap in jurisdiction. Timely disclosure is now a legal requirement, falling within the federal government's power in relation to criminal law and criminal procedure, as well as a professional responsibility requirement, falling within the provincial government's power in relation to the regulation of professions. ${ }^{163}$

\section{(b) Accommodating Overlap: The Ancillary Doctrine}

The ancillary doctrine is of relatively recent origin, and it has not been applied with any consistency by the Supreme Court. ${ }^{164}$ However, the ancillary doctrine did play a prominent role in two of the McLachlin Court's pre-Canadian Western Bank division of powers decisions. In both of these decisions, the Supreme Court affirmed that the ancillary doctrine will be applied to accommodate broad exercises of jurisdiction.

162 Krieger, supra, note 158 , at para. 33.

163 The following cases are also representative of the generous approach that the McLachlin Court consistently took to provincial exercises of jurisdiction: Siemens, supra, note 103 (described above); Pelland, supra, note 109 (described above); UL Canada Inc. v. Quebec (Attorney General), [2005] S.C.J. No. 11, [2005] 1 S.C.R. 143 (S.C.C.) (affirming a judgment of the Quebec Court of Appeal, concluding that a provision in provincial legislation prohibiting the sale of yellow-colour margarine was valid under the provincial property and civil rights power, notwithstanding that it applied to imported as well as locally manufactured margarine; the pith and substance of the legislation was framed as the regulation of intra-provincial trade); British Columbia v. Imperial Tobacco Canada Ltd, [2005] S.C.J. No. 50, [2005] 2 S.C.R. 473 (S.C.C.) [hereinafter "Imperial Tobacco"] (upholding provincial legislation that authorized an action by the government of British Columbia against tobacco product manufacturers for the recovery of the health care expenses it incurred in treating individuals exposed to those products, and altered the common law rules to make it easier for the government to succeed on such an action, notwithstanding that the legislation authorized claims against companies "located" mostly outside the province, for exposure to tobacco products that occurred primarily outside of the province); and Chatterjee, supra, note 23 (a post-Canadian Western Bank decision upholding a provincial civil forfeiture law that largely replicated a federal law, and counselling a second look at Canadian Western Bank and Lafarge, decisions which discouraged "[r]esort to a federalist concept of proliferating jurisdictional enclaves").

164 The story is told in Hogg, Constitutional Law of Canada, supra, note 4, at 15.9(c). 
The first decision in which the ancillary doctrine was applied by the McLachlin Court was Global Securities, discussed above. As noted, in that case, the Supreme Court, per Iacobucci J., sustained a provision in the British Columbia Securities Act authorizing the provincial securities regulator to order registered brokers in that province to produce records to assist in an out-of-province securities investigation. Justice Iacobucci decided the case by applying the pith and substance doctrine. However, in obiter, Iacobucci J. also said that the provision could be sustained under the ancillary doctrine, on the basis that it was sufficiently integral to an otherwise valid provincial legislative scheme.

Two aspects of this decision are important here. First, prior to this case, the ancillary doctrine had been applied only in cases considering the validity of a provision in federal legislation. In this case, Iacobucci J. said that it applied equally to provincial legislation. Second, Iacobucci J. clearly implied that the ancillary doctrine can be used to sustain provisions that might otherwise be unconstitutional under the pith and substance doctrine. ${ }^{165}$ If so, the ancillary doctrine is not merely an alternative to the pith and substance doctrine, used to determine the validity of only part of a legislative scheme. Rather, it permits governments to encroach on the jurisdiction of the other order of government, in a manner that would otherwise violate the division of powers, provided that the provision doing so is sufficiently integral to an otherwise valid scheme.

The pivotal question in applying the ancillary doctrine is the level of scrutiny that will be applied by the court to the challenged provision. This question is pivotal, because where the encroachment is minimal, it is sufficient if the provision is "functionally related" to the legislative scheme, but where the encroachment is not minimal, the provision must be "truly necessary" or "integral" to the legislative scheme. Obviously a provision that encroaches only minimally on the jurisdiction of the other order of government has a much greater chance of surviving a constitutional challenge. ${ }^{166}$

The importance of this determination is evident in the Supreme Court's decision in Kirkbi AG v. Ritvik Holdings Inc., ${ }^{167}$ a case dealing

165 Global Securities Corp., supra, note 63, at para. 45 ("even if s. 141(1)(b) were not in pith and substance provincial, it would clearly be justified under the ancillary doctrine").

166 Earlier decisions seem to treat the degree of encroachment question as a sliding scale, not a question that admits of only two answers - minimal or more than minimal intrusion: see, in particular, the decision of Dickson C.J.C. in General Motors, supra, note 63. However, more recent decisions (which are admittedly far from clear) seem to approach the question in this manner: see Kirkbi, supra, note 63.

167 Supra, note 63. 
with the scope of the federal trade and commerce power (section 91(2)). ${ }^{168}$ At issue in Kirkbi was the passing-off provision (section 7(b)) in the federal Trade-marks Act. ${ }^{169}$ This provision permitted the holder of an unregistered trade mark to recover losses resulting from a person directing "public attention to his wares, services or business in such a way as to cause or be likely to cause confusion in Canada ... with the wares, services or business of another". Ritvik (the manufacturer of Mega Bloks) was engaged in a long-running dispute with Kirkbi (the manufacturer of Lego) over the marketing and sale around the world of Micro Mega Bloks, which closely resembled Lego. Kirkbi, claiming an unregistered trade mark in the Lego design, attempted to restrain Ritvik from marketing Micro Mega Bloks in Canada, by bringing an action under the passing-off provision. Ritvik responded by (among other things) challenging the constitutional validity of the passing-off provision.

An earlier Supreme Court decision seemed to pose a serious challenge to the passing-off provision. ${ }^{170}$ In that decision, Laskin C.J.C. held that a provision in the federal Trade-marks Act creating, as here, a civil cause of action was invalid; the creation of civil causes of action of a contractual or tortious nature fell within provincial jurisdiction, under property and civil rights, section 92(13). But he suggested several times, in obiter, that the result might have been different if the provision establishing the civil cause of action was included in valid federal legislation creating a "regulatory scheme" administered by a "federally-appointed agency" ${ }^{171}$ In doing so, he seemed to place particular emphasis on the idea that the enforcement of the cause of action created by the provision must not be "left to the chance of private redress without public monitor-

168 It has long been established that the trade and commerce power authorizes two types of federal legislation: (a) legislation directed at international or interprovincial trade; and (b) legislation directed at the "general regulation of trade affecting" Canada as a whole: Citizens Insurance Co. of Canada v. Parsons (1881), 7 App. Cas. 96, 113 (P.C.). However, before General Motors, supra, note 63 , the general trade branch of the trade and commerce power was largely ignored or rejected as a basis for sustaining federal legislation. In General Motors, the Supreme Court said that federal legislation would be sustained under the general trade branch of the trade and commerce power if five conditions were satisfied: at 662-63. Applying this approach, the Supreme Court, per Dickson C.J.C., held (for the first time) that the federal Combines Investigation Act, R.S.C. 1970, c. C-23 (now the Competition Act, R.S.C. 1985, c. C-34) was valid as an exercise of the general trade branch of the trade and commerce power. This decision opened up many more legislative options to Parliament, including civil remedies, such as damages. See further Hogg, Constitutional Law of Canada, supra, note 4 , at 18.7 .

169 R.S.C. 1985 , c. T-13, s. 7(b).

170 MacDonald v. Vapor Canada Ltd., [1976] S.C.J. No. 60, [1977] 2 S.C.R. 134 (S.C.C.). Chief Justice Laskin wrote the lead opinion.

$171 \quad I d$, at $156,158,163,165,167$. 
ing by the continued oversight of a regulatory agency". ${ }^{172}$ The passingoff provision seemed to suffer from this exact flaw. The provision was included in a federal regulatory scheme, but the enforcement of the provision was left entirely to the chance of private redress. Only the provisions relating to registered trade marks were subject to federal regulatory oversight.

However, LeBel J., writing for the Supreme Court, held that the passing-off provision was valid under the general trade branch of the trade and commerce power. In reaching this conclusion, he played down the fact that enforcement of the passing-off provision was entirely left to private actors, and played up the role of the provision in the legislative scheme as a whole. The legislative scheme was directed at protecting registered and unregistered trade marks: "without this provision there would be a gap in the legislative protection of trade-marks", and this "would create inconsistencies in the protection of registered and unregistered trade-marks and lead to uncertainty". ${ }^{173}$

The result is that passing off is now subject to both federal jurisdiction, under the trade and commerce power, and provincial jurisdiction, under the property and civil rights power. Yet again, the Supreme Court was unbothered by this result. Justice LeBel acknowledged that the provision "essentially codifies the common law tort of passing off", and that, "[s]tanding alone, it appears to encroach on provincial power." He also conceded, citing General Motors, that the provincial power over property and civil rights "is a significant power and one that is not lightly encroached upon". ${ }^{174}$ Nonetheless, the encroachment here was somehow merely minimal. ${ }^{175}$ Accordingly, it was enough that the provision was merely related to an otherwise valid federal legislative scheme.

This discussion demonstrates the extent to which the McLachlin Court accommodated overlap in jurisdiction in considering challenges to the validity of federal and provincial legislation. In applying the pith and substance doctrine, it permitted both orders of government to enact legislation that substantially impacts the jurisdiction of the other order of government; it allowed both levels of government to enact legislation in particular subject areas, under the double aspect doctrine; and it offered broad new interpretations of (in particular) federal heads of legislative power, by eschewing evidence of original meaning, where this would

\section{$I d .$, at 165.}

Kirkbi, supra, note 63, at para. 36.

Id., at para. 23.

Id., at paras. 23-27. 
narrow the scope of a head of legislative power. In applying the ancillary doctrine, it held that the doctrine would apply to both federal and provincial legislation, and it indicated that it might sustain provisions in both federal and provincial legislation that would otherwise be unconstitutional, provided they were sufficiently integral to a legislative scheme that was valid as a whole.

In some cases, the McLachlin Court broke new ground. For example, the ancillary doctrine had not been applied to provincial legislation before the decision in Global Securities Corp. In many cases, new ground was not broken. For example, the courts have long held that incidental effects are irrelevant to the constitutionality of legislation under the pith and substance doctrine. ${ }^{176}$ But in all cases, division of powers doctrine, new and old, was applied to accommodate overlap in legislative jurisdiction.

The McLachlin Court did not completely eschew a role in defining the boundaries of federal and provincial legislative power. In the Firearms Reference, for example, it said that it would intervene where the impact of a legislative measure on the jurisdiction of the other order of government was so substantial that it was absolutely clear that the legislative measure was actually directed to a matter falling within the jurisdiction of that order of government. Similarly, in the Employment Insurance Reference, it said that the scope of the heads of legislative power may change to meet new political, social and economic realities, but that the change must be consistent with the "natural" evolution of the power. However, in both rhetoric and result, the message was fairly clear: the legislative branches have considerable flexibility to set the federalprovincial balance of power; the Supreme Court will intervene to limit the scope of legislative power, but only where one order of government dramatically upsets the existing balance of power.

\section{(c) Accommodating Exclusivity?: The Interjurisdictional Immunity Doctrine}

The doctrine of interjurisdictional immunity has figured prominently in debates, judicial and academic, about the proper balance of power, and the judicial role in protecting that balance of power. For those who believe that there are (at least some) zones of exclusive federal jurisdiction (or federal and provincial jurisdiction) that must be respected, the doctrine of interjurisdictional immunity has an important role to play in a

176 Hogg, Constitutional Law of Canada, supra, note 4, at 15.5(a). 
division of powers analysis - and the courts, in turn, have a role to play in applying it. ${ }^{177}$ However, for those who believe that there are very few (or no) zones of exclusive federal jurisdiction (or federal and provincial jurisdiction) that must be respected, the doctrine of interjurisdictional immunity has a limited (or no) role to play in a division of powers analysis - and the courts, in turn, have a limited (or no) role to play in applying it. ${ }^{178}$

In Canadian Western Bank, the Supreme Court significantly restricted the application of the doctrine of interjurisdictional immunity. Consistent with its approach to the pith and substance doctrine and the ancillary doctrine, it did so, ostensibly, in order to limit zones of exclusive jurisdiction, and to accommodate overlap in jurisdiction.

Although important, this change ought not to have been entirely unexpected, for two reasons. The first is the decision in Law Society of British Columbia v. Mangat, ${ }^{179}$ the only non-section 91(24) decision of the McLachlin Court to address the doctrine of interjurisdictional immunity prior to Canadian Western Bank. ${ }^{180}$ In that case, the Supreme Court expressed doubts about the doctrine of interjurisdictional immunity, and said that it was preferable to look to the paramountcy doctrine in deciding the case. ${ }^{181}$ This was so for two reasons. The first was that the doctrine of interjurisdictional immunity "would exclude provincial juris-

177 See, e.g., R. Elliot, Comment (1988) 67 Can. Bar Rev. 523 (defending the doctrine of interjurisdictional immunity); Bell Canada, supra, note 73, at paras. 248-304, per Beetz J. (same).

178 See, e.g., D. Gibson, Comment (1990) 69 Can. Bar Rev. 339 (criticizing the doctrine); and OPSEU, supra, note 102, at 17-22, per Dickson C.J.C. (dissenting) (Lamer J. concurring) (same).

179 [2001] S.C.J. No. 66, [2001] 3 S.C.R. 113 (S.C.C.) [hereinafter “Mangat”].

180 The McLachlin Court did consider the doctrine of interjurisdictional immunity in four s. 91(24) decisions prior to Canadian Western Bank: see Lovelace, supra, note 12, at paras. 109-111; Kitkatla Band, supra, note 12, at paras. 67-71; Paul, supra, note 12, at paras. 14-34; and Morris, supra, note 12, at paras. 41-43. Concerns about the doctrine of interjurisdictional immunity were not raised by the Supreme Court in any of these decisions. However, I am reluctant to draw any conclusions from this fact. As noted above (see note 12), the federal legislative power provided for in s. 91(24) raises unique considerations. It may simply be the case that the Supreme Court was hesitant to apply its larger concerns about the interjurisdictional immunity doctrine to s. 91(24), because it was reluctant to circumscribe the operation of the doctrine in relation to s. 91(24) without a discussion of the unique considerations at play in that context. However, even if I am wrong about this, my analysis would not change. The Supreme Court did not completely discard the doctrine of interjurisdictional immunity in Canadian Western Bank; it said, rather, that it should be applied with considerable caution. Even the most superficial analysis of these four s. 91(24) decisions reveals a similarly cautious approach. With the exception of Morris, the Supreme Court did not even consider whether the core of federal competence was affected or impaired, because the core was said not to be engaged at all; and in Morris, where the core was engaged and immunity was granted, the majority used the stricter language of impairs, not affects (see paras. 42-43).

181 Mangat, supra, note 179, at paras. 52-54. I discuss the case in further detail below. 
diction, even if Parliament did not legislate in the area"; it was preferable to rely on the paramountcy doctrine, because it did not lead to regulatory vacuums of this sort. The second was that the doctrine of interjurisdictional immunity might lead to bifurcated regulation; it was preferable to rely on the paramountcy doctrine, because it would protect federal and provincial jurisdiction. ${ }^{182}$

It is tempting to treat Mangat as an anomaly. It is only one decision; in the 1990s, the Supreme Court did treat the doctrine of interjurisdictional immunity as an accepted feature of a division of powers analysis in a series of decisions, ${ }^{183}$ and in two of these decisions, one released as recently as 1998, the Supreme Court actually applied the doctrine and read down provincial laws. ${ }^{184}$ However, just years earlier, in 1987, Dickson C.J.C. (Lamer J. concurring) argued that the doctrine ought to be applied cautiously, because it operated to limit the "fair amount of interplay and indeed overlap between federal and provincial powers" that was the hallmark of the Canadian division of powers. ${ }^{185}$ And in $1989,{ }^{186}$ the Supreme Court signalled its dissatisfaction with the doctrine, by introducing a nonsensical qualification that restricted its application. ${ }^{187}$ Although the Supreme Court seemed to put its concerns about the doctrine to rest in the 1990s, Mangat indicated that these concerns remained, or had, in the least, resurfaced.

However, Mangat aside, there is another, even more compelling reason that Canadian Western Bank ought not to have come as a big surprise. In restricting the application of the doctrine of interjurisdictional immunity, the Supreme Court was merely squaring the manner in

182 Id., at para. 52.

183 Friends of the Oldman River Society v. Canada (Minister of Transport), [1992] S.C.J. No. 1, [1992] 1 S.C.R. 3 (S.C.C.) (immunity from federal law denied); Ontario Hydro v. Ontario (Labour Relations Board), [1993] S.C.J. No. 99, [1993] 3 S.C.R. 327 (S.C.C.) (same); R. v. Canadian Pacific Ltd., [1995] S.C.J. No. 6, [1995] 2 S.C.R. 1028 (S.C.C.) (immunity from provincial law denied); Air Canada v. Ontario (Liquor Control Board), [1997] S.C.J. No. 66, [1997] 2 S.C.R. 581 (S.C.C.) (same).

${ }_{184}$ Canada (National Battlefields Commission) v. CTCQ, [1990] S.C.J. No. 90, [1990] 2 S.C.R. 838 (S.C.C.) (immunity from provincial law granted); Ordon Estate v. Grail, [1998] 3 S.C.R. 437 (same).

185 OPSEU, supra, note 102, at 17-22.

186 Irwin Toy Ltd. v. Quebec (Attorney General), [1989] S.C.J. No. 36, [1989] 1 S.C.R. 927, at 955-57 (S.C.C.). Irwin Toy was released only 11 months after Bell Canada, and four of the five judges who sat on Irwin Toy also sat on Bell Canada (including Beetz J., who wrote the judgment in Bell Canada). The case raised a division of powers and a Charter issue. The bench was unanimous on the division of powers issue, but split on the Charter issue. The lead judgment on the division of powers issue was written by Dickson C.J.C.

187 See Canadian Western Bank, supra, note 8, at para. 49 (affirming this reading). 
which it applied the doctrine with its overall theory of judicial review. As noted, the doctrine of interjurisdictional immunity operates to protect exclusive enclaves of legislative power, and it does so whether or not the other level of government has enacted overlapping legislation in that area. However, in both rhetoric and result, the McLachlin Court consistently accommodated overlap in jurisdiction in its division of powers cases, in applying both the pith and substance doctrine and the ancillary doctrine. It would be incongruous for the Supreme Court to embrace overlap in applying the pith and substance and the ancillary doctrines, but to reject it in applying the doctrine of interjurisdictional immunity. ${ }^{188}$ Taken in context, the decision in Canadian Western Bank was not unexpected - doctrine was merely being squared with theory.

\section{(d) Managing Intergovernmental Conflict: The Paramountcy Doctrine}

In 1988, in Bell Canada, Beetz J., writing for the Supreme Court, cautioned that the pith and substance doctrine and the double aspect doctrine must be applied with great caution because there is a "risk that these two fields of exclusive powers [in sections 91 and 92 of the Constitution Act, 1867] will be combined into a single more or less concurrent field of power governed solely by the rule of paramountcy of federal legislation". ${ }^{189}$ Twenty years later, in Canadian Western Bank, the Supreme Court threw caution to the wind and basically adopted this approach. The Supreme Court made it clear that it would largely limit itself, not to imposing absolute limits on jurisdiction, but to managing jurisdictional overlap, by interpreting overlapping legislation to avoid conflict in operation, if possible, and applying the paramountcy doctrine in the situations that remain. This approach was already firmly entrenched in the McLachlin Court's prior division of powers decisions.

The paramountcy doctrine figured prominently in three decisions released by the McLachlin Court prior to Canadian Western Bank: 114957 Canada Ltée (Spraytech, Société d'arrosage) v. Hudson (Town); ${ }^{190}$

188 For those who believe that the courts ought to protect exclusive enclaves of federal and provincial power, such an approach is likely to be seen as anything but incongruous. My point here is merely that it would be incongruous for a court that seems intent on accommodating significant overlap in federal and provincial jurisdiction to embrace it in applying one doctrine (the pith and substance doctrine), but to eschew it in applying another (the interjurisdictional immunity doctrine).

189 Bell Canada, supra, note 73, at 766.

190 [2001] S.C.J. No. 42, [2001] 2 S.C.R. 241 (S.C.C.). 
Mangat ${ }^{191}$ and Rothmans, Benson \& Hedges v. Saskatchewan. ${ }^{192}$ One aspect of these decisions is emphasized in the academic literature namely, the extent to which the McLachlin Court affirmed two extensions of the definition of conflict. ${ }^{193}$ It is understandable that this aspect of these decisions has received considerable attention. The Supreme Court did affirm that a conflict will not be triggered merely where it is impossible to comply with both a federal and a provincial law, but that a conflict will also be triggered where the operation of a provincial law would frustrate the purpose of a federal law. ${ }^{194}$ It also affirmed that the stricter impossibility of dual compliance test will not be engaged merely where a citizen cannot comply with both laws, but that it will also be engaged where a government decision-maker cannot comply with (or give effect to) both laws. ${ }^{195}$ By expanding the definition of conflict in these two ways, the Supreme Court did increase the situations in which federal law might pre-empt provincial law. However, it seems to me that a different, and equally important, aspect of these decisions has largely been ignored in the academic literature. This aspect of the decisions emerges, not so much from what the Supreme Court says, but from what it does. Shifting the focus to results, away from the rhetoric, the primary concern of the Supreme Court seems to be intergovernmental conflict (meaning conflicts in the positions taken by the relevant government actors), not legislative conflict (meaning conflicts stemming from the operation of the legislation). The Supreme Court seems to be concerned with legislative conflict only secondarily, where there is an intergovernmental conflict about jurisdiction; where there is no intergovernmental conflict, the Supreme Court is reluctant to find a legislative conflict.

191 Supra, note 179.

192 Supra, note 102. See also Garland v. Consumers' Gas Co., [2004] S.C.J. No. 21, [2004] 1 S.C.R. 629, at paras. 50-53 (S.C.C.) (discussing the paramountcy doctrine briefly; the case did not turn on the paramountcy doctrine, but on unjust enrichment, so I do not discuss it here); and D.I.M.S. Construction Inc. (Trustee of) v. Québec (Attorney General), [2005] S.C.J. No. 52, [2005] 2 S.C.R. 564 (S.C.C.) (finding that two provisions in Quebec legislation did not affect the order of priorities in bankruptcy proceedings in a manner inconsistent with the federal bankruptcy legislation, and thus that there was no conflict; the paramountcy doctrine is not specifically mentioned).

193 P.W. Hogg, "Paramountcy and Tobacco" (2006) 34 S.C.L.R. (2d) 355 (emphasizing this element of the decisions); R. Elliot, "Safeguarding Provincial Autonomy from the Supreme Court's New Federal Paramountcy Doctrine" (2007) 38 S.C.L.R. (2d) 629 [hereinafter "Elliot, 'Safeguarding Provincial Autonomy"'] (same); Brouillet, "The Federal Principle", supra, note 7, at 325-32 (same); Ryder, "The End of Umpire?", supra, note 7, at 369-72 (same).

194 Mangat, supra, note 179, at paras. 70, 72 (citing Bank of Montreal v. Hall, [1990] S.C.J. No. 9, [1990] 1 S.C.R. 121 (S.C.C.)).

195 Id., at paras. $71-72$ (citing M \& D Farm Ltd. v. Manitoba Agricultural Credit Corp., [1999] S.C.J. No. 4, [1999] 2 S.C.R. 961 (S.C.C.)). 
How is this reflected in the decisions? Consider Rothmans. In that case, federal legislation prohibited the promotion, anywhere in Canada, of tobacco products, except as authorized elsewhere in the legislation (section 19), and it later provided that "a person may display, at retail, a tobacco product" (section 30(1)). ${ }^{196}$ However, Saskatchewan legislation prohibited the advertising, promotion and display of tobacco products in any premises in the province in which persons under the age of 18 were permitted (section 6). ${ }^{197}$ At issue was whether the Saskatchewan legislation was rendered inoperative by the paramountcy doctrine. A number of major tobacco companies, including Rothmans, Benson and Hedges, argued that the answer was yes; the government of Saskatchewan (supported by the federal government and several provinces) argued that the answer was no.

The Supreme Court, per Major J., agreed with the province. There was no concern about impossibility of dual compliance. The federal legislation did not create a "positive entitlement" to display tobacco products, but merely circumscribed the general prohibition on promotion; accordingly, it was possible for a retailer to comply with both provisions (either by refusing to admit persons under 18 or not displaying tobacco products) and for a judge to give effect to both provisions (by proceeding on the assumption that the provincial legislation simply prohibits what the federal legislation does not prohibit). ${ }^{198}$ In addition, there was no concern about frustrating the federal purpose. The provincial legislation did not frustrate either the general purpose of the federal legislation ("to address a national health problem") or the specific purpose of the challenged provision ("to circumscribe the [federal legislation's] general prohibition on promotion of tobacco products"). ${ }^{199}$ On the contrary, the provincial legislation furthered "at least two of the stated purposes of the [federal legislation,] namely, 'to protect young persons and others from inducements to use tobacco products' (s. 4(b)), and 'to protect the health of young persons by restricting access to tobacco products' (s. 4(c))". ${ }^{200}$

The Supreme Court gave short shrift to two arguments supporting the opposite conclusion, ${ }^{201}$ both of which were accepted by the Saskatche-

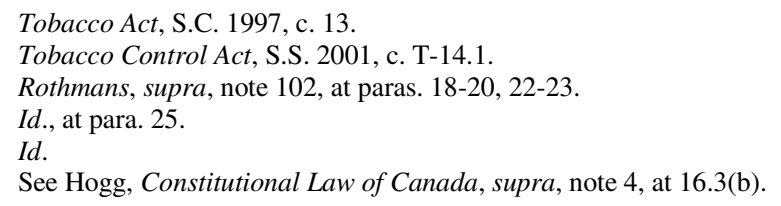


wan Court of Appeal. ${ }^{202}$ The first argument was that the provincial legislation frustrated the specific purpose of the provision in the federal legislation permitting retail display. The choice seemed to be quite simple: a retail establishment that wanted to display tobacco products (as permitted by the federal legislation) could comply with both the federal and provincial legislation by excluding persons under 18 from the establishment (as required by the provincial legislation). However, given the impracticality in many cases of excluding persons under 18, many retail establishments had little choice but to refrain from displaying tobacco products. For these establishments, the provincial legislation effectively negated the exception in the federal legislation relating to retail display. The second argument was that the provincial legislation frustrated a general purpose of the federal legislation. In RJR-MacDonald, the majority of the Supreme Court held that the predecessor to the federal legislation at issue in Rothmans unjustifiably infringed the right to freedom of expression in section 2(b) of the Charter, and in so doing, expressed concerns about an absolute ban on promotion. ${ }^{203}$ The federal government responded by enacting legislation that prohibited the promotion of tobacco products, but permitted retail display. However, Saskatchewan then enacted legislation restricting retail display. There was an argument that, in doing so, the provincial legislation frustrated a general purpose of the federal legislation - to regulate tobacco products in a manner that complied with the Charter.

The Supreme Court did not accept either argument. It simply ignored the Charter argument, and it asserted, without explanation, that the specific purpose of the provision in the federal legislation permitting retail display was not frustrated by the provincial legislation. The Supreme Court was clearly reluctant to find the provincial law inoperative under the paramountcy doctrine. But why? The answer may lie, in part, in the fact that the Supreme Court simply agreed with the provincial law; "big tobacco" has not fared well in the Supreme Court in recent years. ${ }^{204}$ However, the answer likely also lies, at least in part, in the fact that this was a case in which there was no intergovernmental conflict. The federal

202 Rothmans, Benson \& Hedges Inc. v. Saskatchewan, [2003] S.J. No. 606, 232 D.L.R. (4th) 495, 238 Sask. R. 530, at paras. 69-88 (Sask. C.A.).

203 Supra, note 124, at paras. 164, 191.

204 See e.g., Imperial Tobacco, supra, note 163 (rejecting a constitutional challenge to a provincial law making it considerably easier for the provincial government to recover its tobaccorelated healthcare costs); and Canada (Attorney General) v. JTI-Macdonald Corp., [2007] S.C.J. No. 30, [2007] 2 S.C.R. 610 (S.C.C.) (rejecting a constitutional challenge to a federal statute placing significant restrictions on tobacco advertising). 
government intervened to support the law, arguing that it was enacted for the same health-related purpose as the federal law. The Supreme Court noted that it was influenced by the federal government's submissions. ${ }^{205}$

Now consider Mangat. One of the issues in Mangat was whether a provincial law that had the effect of preventing non-lawyers from appearing for a fee before the federal Immigration and Refugee Board ("IRB") was rendered inoperative, under the paramountcy doctrine, by a federal law that authorized non-lawyers to appear before the IRB for a fee. The Supreme Court, per Gonthier J., said yes. There was no conflict, applying the narrow impossibility of dual compliance test: those appearing before the IRB could comply with both provisions, either by becoming a lawyer or by not charging a fee for their services. But there was nonetheless still a conflict in operation, for two reasons. First, the purpose of the federal rule was to provide an informal, accessible and speedy process before the IRB, in which clients could be represented by those who spoke their language, understood their culture and were inexpensive; that purpose would be frustrated if only lawyers were permitted to appear before the IRB. And second, "it would be impossible for a judge or an official of the IRB to comply with both acts". ${ }^{206}$

Of the three cases listed above, Spraytech, Mangat and Rothmans, Mangat was the only case in which the Supreme Court held that there was a conflict sufficient to trigger the paramountcy doctrine. What might account for this different result? Unlike Spraytech and Rothmans, this was a case where there was an intergovernmental conflict. The federal government intervened before the Supreme Court, emphasizing the important role that immigration consultants played in proceedings before the IRB, and arguing that it would frustrate the purpose of the federal legislation to apply the provincial legislation to prohibit nonlawyer immigration consultants from appearing for a fee before the IRB. The Supreme Court agreed, and held the provincial legislation to be inoperative.

Results speak louder than words in these cases. Where there is no intergovernmental conflict, the Supreme Court is reluctant to find provincial legislation inoperative under the paramountcy doctrine: it strives, where possible, to ensure the ordinary operation of the legislation of both levels of government, by interpreting the legislation to avoid conflict (Rothmans). However, where there is intergovernmental conflict, the Supreme Court is 
less reluctant to find provincial legislation inoperative under the paramountcy doctrine (Mangat). It is not especially surprising to see this dynamic at work in the paramountcy decisions. Why? A central concern of a paramountcy analysis is now avoiding the frustration of federal legislative purpose. A court, like the current Supreme Court, that is content to let the political branches take the lead in defining the balance of power is unlikely to be keen on substituting its view for the federal government's view of federal purpose, particularly in a case where there is no intergovernmental conflict, and the federal government supports the operation of a provincial law. Rightly or wrongly, ${ }^{207}$ such a court is likely to take the view that the federal government is better positioned to determine the purpose of federal legislation.

The role that intergovernmental conflict now plays in the Supreme Court's paramountcy decisions is demonstrated particularly clearly in Lafarge ${ }^{208}$ released concurrently with Canadian Western Bank. At issue was a proposal to build an integrated ship offloading/concrete batching facility. The facility was to be built on land owned by the Vancouver Port Authority (the "VPA"), but situated within the City of Vancouver. The stage was set for a jurisdictional struggle: the regulatory regime established by the federal Canada Marine Act ${ }^{209}$ authorized the VPA to regulate land use on port lands managed and owned by the VPA, but the City of Vancouver had also enacted a zoning and development by-law regulating land use within Vancouver city limits. ${ }^{210}$ However, as might be expected, the case was not initiated by either the VPA or the City of Vancouver: the Lafarge proposal was approved in principle by both. The case was initiated by a group of local ratepayers opposed to the construction of the facility in their neighbourhood. The basis of their legal claim was the failure of the City of Vancouver to require a development permit, in accordance with its own zoning and development by-law. Lafarge and the VPA argued in response that a development permit was not required, by virtue of the doctrine of interjurisdictional immunity (on the basis that the VPA had the exclusive jurisdiction to deal with land-use regulation

207 Of course, there are often good reasons to be skeptical of a government's statement of legislative purpose. For example, the government in power at the time of the case might be a very different one than was in power when the legislation was enacted - it might even have opposed the legislation - and its motives in taking the position it takes regarding legislative purpose might be of a highly political nature. However, that issue is beyond the scope of this paper, and not critical to the point I am making here.

208 Supra, note 8.

209 S.C. 1998 , c. 10.

210 City of Vancouver Zoning and Development Bylaw No. 3575. 
on VPA-owned land) and/or the paramountcy doctrine (on the basis that the VPA and the City of Vancouver land-use controls conflicted).

Surprisingly, the Supreme Court, per Binnie and LeBel JJ., held that there was a conflict between the federal and municipal land-use regimes. In so concluding, the Supreme Court seemed to abandon the posture of restraint articulated in Canadian Western Bank and its earlier paramountcy decisions. There would seem to be no impossibility of dual compliance simply where both a federal law and a municipal by-law require separate zoning and development approvals. The conflict will arise only where one order of government withholds its approval. If both orders of government consent, there would be no conflict, and it should (in theory, at least) be possible to obtain the consent of both orders of government, by complying with the stricter standards. However, the Supreme Court said nonetheless that the impossibility of dual compliance test of conflict was satisfied on these facts, due to simple differences in height restrictions and noise and pollution standards. It also said that the frustration of federal purpose test of conflict was satisfied, although the purpose of the federal law was never identified.

What might account for this result? The answer seems to be the $\mathrm{Su}-$ preme Court's desire to accommodate intergovernmental dialogue. The federal government had delegated regulatory authority to the VPA and the provincial government had delegated regulatory authority to the City of Vancouver, and both the VPA and the City had approved the Lafarge proposal. This seemed to be decisive for the Supreme Court. This passage from the Supreme Court's decision is particularly striking in this regard:

A successful harbour in the 21 st century requires federal provincial cooperation. The courts should not be astute to find ways to frustrate rather than facilitate such cooperation where it exists if this can be done within the rules laid down by the Constitution.

Here the VPA and the City worked out a cooperative framework. The Lafarge project, although opposed by the Ratepayers, complied with the land use envisaged by both levels of government in their respective planning documents.

Of course, consent cannot confer jurisdiction where none exists. In this case, however, the project was found by those most closely concerned in ... to be dealt with through federal rather than municipal procedures. No reason has been shown for us to interfere. 
Where the VPA and the City are in disagreement, of course, the courts will have to resolve the difference. But that is not this case. ${ }^{211}$

The Supreme Court is clearly anxious to facilitate intergovernmental dialogue, and in this case, interestingly enough, this compels the Supreme Court to act. The Supreme Court finds a conflict between the federal and the municipal regulatory regime, in order to preserve the fruits of the cooperation of these two stakeholders. ${ }^{212}$ The ratepayers are, it seems, mere busybodies, insufficiently "closely concerned" to justify "interfering".

This brings to the surface an important implication of the Supreme Court's theory of judicial review. The traditional view is that both governments and private parties are entitled to hold governments to the division of powers, and that courts should take seriously division of powers challenges initiated by private parties. This view was challenged over 30 years ago by Paul Weiler. ${ }^{213}$ Working from an assumption that the division of powers engages individual interests in a limited way, if at all, Weiler argued that courts should generally refuse to entertain nongovernment division of powers claims. Thirty years later, Weiler's argument seems to hold considerable purchase with the Supreme Court. The Supreme Court did continue to hear division of powers cases initiated by private parties; it regularly denied that federal-provincial agreement about jurisdiction is determinative of constitutionality; and in one case, it even explicitly disclaimed the view that the division of powers does not engage private interests. ${ }^{214}$ However, it also said, time and again, that it

211 Lafarge, supra, note 8, at paras. 86-88, 90.

212 The Supreme Court is being somewhat slippery here. In Lafarge, the Government of British Columbia defended the position of the ratepayers that there was no conflict between the federal and the municipal regulatory regime; this pitted the ratepayers and the Government of British Columbia against the City of Vancouver (the municipal regulatory authority, granted that authority by the province), the VPA (the federal regulatory authority) and the federal government (which intervened). In finding a conflict, the Supreme Court was, in fact, preserving federal-municipal not federal-provincial cooperation.

213 P. Weiler, In The Last Resort, supra, note 40, at c. 6.

214 Kitkatla Band, supra, note 12, at para. 72 (emphasis added) (citing OPSEU, supra, note 102, at 19-20 per Dickson C.J.C. (dissenting)):

The distribution of powers provisions ... do not have as their exclusive addressees the federal and provincial governments. They set boundaries that are of interest to, and can be relied upon by, all Canadians. Accordingly, the fact of federal-provincial agreement on a particular boundary between their jurisdictions is not conclusive of the demarcation of that boundary. Nevertheless, in my opinion the Court should be particularly cautious about invalidating a provincial law when the federal government does not contest its validity or, as in this case, actually intervenes to support it and has enacted legislation based on the same constitutional approach adopted by Ontario. 
would be particularly hesitant to strike down a legislative measure in the face of intergovernmental dialogue. Moreover, private citizens have regularly failed in challenging legislation absent intergovernmental conflict. The implication seems fairly clear. For the Supreme Court, there is a sharp distinction between judicial review under the Charter and the division of powers: Charter review is seen to engage individual interests, whereas federalism review is not, at least not directly. For that reason, private division of powers challenges that do not garner the support of the non-enacting order of government are approached with caution.

\section{(e) Summary}

In its division of powers decisions, the McLachlin Court consistently adopted the approach it later outlined in Canadian Western Bank. It regularly accommodated overlap in jurisdiction in the manner in which it applied both the pith and substance doctrine and the interjurisdictional doctrine. It largely limited itself to managing overlapping legislation: where there was no intergovernmental conflict, it was reluctant to find a legislative conflict, and typically attempted to ensure the operation of the legislation of both orders of government, by interpreting the legislation to avoid conflict in operation; where there was an intergovernmental conflict, it still attempted to interpret legislation to limit conflict in operation, but it was less reluctant to apply the paramountcy doctrine.

The approach adopted in these decisions is reflective of the theory of judicial review outlined by the Supreme Court in Canadian Western Bank. As in Canadian Western Bank, the Supreme Court, in these decisions, did not entirely leave the division of powers to the political branches. It encouraged the political branches to take the lead in setting the balance of power, but implied that it would still be prepared to intervene in situations where either order of government dramatically upset the balance of power.

The last element of the theory of judicial review outlined in Canadian Western Bank, facilitating intergovernmental dialogue, is reflected less overtly. However, on closer inspection, it is also quietly at work in these decisions as well. The paramountcy decisions are particularly interesting. The Supreme Court was reluctant to find a conflict in operation where there was no intergovernmental conflict about jurisdiction, but it was less reluctant to do so where there was an intergovernmental con- 
flict. As in Canadian Western Bank, the motivation seemed to be to facilitate intergovernmental dialogue.

These decisions also provide further insight into this theory of judicial review. For example, under this theory, private litigants have a reduced chance of success, particularly where the legislation at issue reflects some form of intergovernmental dialogue. The paramountcy cases demonstrate the point - the Supreme Court has been reluctant to find an operative conflict absent intergovernmental conflict. The decisions also provide insight into the Supreme Court's understanding of intergovernmental dialogue. In short, it appears to mean, simply, agreement. Little emphasis is placed on how agreement is reached; what matters most, it seems, is the mere fact of agreement. Finally, these decisions highlight an interesting role for judicial review: court challenges now seem to serve as an opportunity for intergovernmental dialogue about jurisdiction.

\section{FUtURE DiRECTIONS?: POST-CANADIAN WESTERN BANK}

The theory of judicial review described in Canadian Western Bank continues to animate the Supreme Court's subsequent division of powers decisions. ${ }^{215}$ However, in these decisions the Supreme Court is increasingly being forced to grapple with difficult questions flowing from its embrace of this theory of judicial review. In this section, I outline three such questions. I then anticipate an argument that would, if convincing, answer, or in the least change the nature of the debate about, these questions. I do not consider the strengths or weaknesses of this argument here; that is left to a future paper.

215 See Confédération des syndicats, supra, note 150 (embracing an even broader reading of the federal unemployment insurance power, and upholding various measures directed, not at income replacement, as per the Employment Insurance Reference, but at improvising access to the labour market); Chatterjee, supra, note 23 (upholding a provincial civil forfeiture law that largely replicates a federal criminal forfeiture law, and dismissing the argument as "based ... on an exaggerated view of the immunity of federal legislation in relation to matters that may, in another aspect, be the subject of provincial legislation”, and counselling a second look at Canadian Western Bank and Lafarge, supra, note 8); but see Consolidated Fastfrate, supra, note 151 (finding that the employees of a freight forwarding company fell within provincial jurisdiction, and affirming the basic principles of Canadian Western Bank, supra, note 8, at paras. 29-30, but placing more emphasis on original intent than has traditionally been evident in prior decisions, which elicited a strong dissent from Binnie J., one of the co-authors of Canadian Western Bank). 


\section{The Role of Intergovernmental Dialogue}

One important question that the Supreme Court has failed to address in an authoritative manner is the role that intergovernmental dialogue will (and should) actually play in division of powers cases. A court asked to consider the constitutionality of a legislative measure reflecting some element of intergovernmental dialogue could adopt one of four different approaches. First, it could hold that the division of powers forbids all legislative measures resulting from intergovernmental dialogue. On this view, intergovernmental dialogue is a negative factor in assessing constitutionality. Second, it could hold that the division of powers does not forbid legislative measures resulting from intergovernmental dialogue, but insist that all such legislative measures must respect the division of powers as it stands. On this view, intergovernmental dialogue is at best a neutral factor in assessing constitutionality. Third, it could hold, not only that the division of powers does not forbid legislative measures resulting from intergovernmental dialogue, but that the division of powers should actually be altered, in some cases, at least, to accommodate intergovernmental dialogue. On this view, intergovernmental dialogue is a positive factor in assessing constitutionality. Or fourth, it could hold that intergovernmental dialogue should be decisive in all cases. The Supreme Court has sent mixed signals as to which approach it supports. There is language in Supreme Court decisions supporting the second approach; this is reflected in its claim that intergovernmental agreement is not determinative of constitutionality. ${ }^{216}$ However, there is strong evidence that the Supreme Court is actually inclined to the third approach: intergovernmental dialogue is not necessarily decisive, but it is a positive factor to take into account in determining whether an exercise of jurisdiction is constitutional. $^{217}$

This question is raised squarely in Canada (Attorney General) v. Quebec (Attorney General). At issue in that case is the constitutionality of various provisions in the federal Assisted Human Reproduction Act. ${ }^{218}$ That legislation establishes a detailed federal framework for the regula-

216 See supra, note 214

217 It seems fairly clear that intergovernmental dialogue is not a condition precedent (a necessary condition) to constitutionality: see Firearms Reference, supra, note 114, at para. 56 (rejecting an argument that the lack of consultation by the federal government with the provinces before enacting federal gun control legislation reflected negatively on the legislation's constitutionality); see also Reference re Anti-Inflation Act, [1976] S.C.J. No. 12, [1976] 2 S.C.R. 373, at 421 (S.C.C.) (rejecting a similar argument about federal anti-inflation legislation).

218 S.C. 2004 , c. 2. 
tion of assisted human reproduction. In 2007, Quebec tabled its own legislation, and then referred various provisions in the federal legislation to the Quebec Court of Appeal. The Court of Appeal agreed with the province that the provisions in question were unconstitutional. ${ }^{219}$ The federal government appealed. The Supreme Court heard argument in the case in April of last year and reserved judgment. ${ }^{220}$

The case raises the question of intergovernmental dialogue, because the federal legislation includes a provision (section 68) that allows certain provisions in it to be suspended in a province by agreement, provided that province has enacted "equivalent", but not necessarily identical, regulatory standards. In prior cases, the Supreme Court seemed to take comfort in provisions of this sort in finding federal legislation to be constitutional. ${ }^{221}$ However, the Quebec Court of Appeal adopted quite a different approach. It suggested, in essence, that section 68 actually counted against, not in favour of, the provisions. Its reasoning is difficult to follow, but the general thrust seems to be that, by contemplating the possibility of "equivalent" standards, Parliament effectively conceded that its purpose was the regulation of health, an area falling within provincial jurisdiction. ${ }^{222}$

The Government of Quebec did not pursue this particular argument before the Supreme Court. ${ }^{223}$ Rather, it argued that provisions of this sort can have no bearing on constitutionality, by rendering constitutional an otherwise unconstitutional exercise of legislative power. In support, it pointed to section 94 of the Constitution Act, 1867, a little-known and rarely discussed constitutional provision that allows the federal Parliament to legislate, with provincial consent, "for the Uniformity of all or any of the Laws relative to Property and Civil Rights in Ontario, Nova Scotia, and New Brunswick". ${ }^{224}$ This argument goes directly to the question of the effect of intergovernmental dialogue on constitutionality. The argument is, in essence, that it is inappropriate for the Supreme Court to take intergovernmental dialogue into account in a division of powers case, because the text of the Constitution itself imposes certain procedural and substantive limits on the ability of Parliament to legislate

\footnotetext{
219 [2008] J.Q. no 5489, 298 D.L.R. (4th) 712 (Que. C.A.).

220 Case No. 32750 (Appeal heard April 24, 2009).

221 See, e.g., Siemens, supra, note 103, and Confédération des syndicats, supra, note 150.

222 Supra, note 219, at para. 145.

223 See Factum of the Attorney General of Quebec (March 16, 2009), available online: $<$ http://www.scc-csc.gc.ca/case-dossier/cms-sgd/fac-mem-eng.aspx?cas=32750>.

224 Section 94 was recently discussed at length in Marc-Antoine Adam, "The Spending Power, Co-operative Federalism and Section 94” (2008) 34 Queen’s L.J. 175.
} 
outside its jurisdiction. Intergovernmental dialogue, on this argument, is at best a neutral factor in considering constitutionality.

Before the Supreme Court, the federal government limited itself to confronting the Quebec Court of Appeal's argument that section 68 actually counted against the impugned provisions. ${ }^{225}$ It argued that the federal Parliament actually had the jurisdiction to enact the provisions under its criminal law power, and pointed to previous cases in which the Supreme Court seemed to suggest that section 68-type provisions were a valid response to the need for a certain degree of cooperation and coordination between federal and provincial authorities in fields where, as here, both orders of government have jurisdiction.

Quebec raises an interesting point. What is the importance of section 94 in considering the effect of intergovernmental dialogue on constitutionality? Does it count against the argument that it is appropriate for the Supreme Court to bend the division of powers to facilitate intergovernmental dialogue, on the basis that it sets particular textual limits on the ability of governments to agree to otherwise unconstitutional exercises of legislative power by the other order of government? Or does it actually count in favour of the argument that it is appropriate for the Supreme Court to do so, on the basis that it shows that intergovernmental dialogue was actually a positive objective of the drafters?

This feeds into even broader questions about the effect of intergovernmental dialogue on constitutionality. Is intergovernmental dialogue a positive or neutral factor in determining constitutionality? In answering this question, does it matter that the federal legislation purports to apply in a province until that province decides to legislate in respect of assisted human reproduction? Does it matter that a province may not opt out of the federal legislation until it has in force "equivalent" regulations, which coerces the provinces into accepting, roughly, the minimum federal standards? ${ }^{226}$ Does it matter that legislation is structured to accommodate

225 Factum of the Attorney General of Canada (January 16, 2009), available online: $<$ http://www.scc-csc.gc.ca/case-dossier/cms-sgd/fac-mem-eng.aspx?cas=32750>.

226 The United States Supreme Court has found unconstitutional certain attempts by the federal government to coerce the states: see, e.g., New York v. United States, 505 U.S. 144, at 188 (1992) (concluding that it was "clear" that "[t]he Federal Government may not compel the States to enact or administer a federal regulatory program", and striking down a federal law that provided that state governments would "take title" to radioactive waste within borders that were not disposed of by a certain date); and Printz v. United States, 521 U.S. 898 (1997) (reaffirming New York v. United States, and striking down a federal law that required state and local law enforcement officers to conduct background checks on prospective handgun purchasers); but see Reno v. Condon, 528 U.S. 141 (2000) (refusing to strike down a federal law that prohibited a state from disclosing personal 
interlocking provincial legislation, if a province(s) objects to the exercise of federal jurisdiction on the whole?

The case highlights these important questions about the role that intergovernmental dialogue will and ought to play in determining the constitutionality of an exercise of legislative power. It would not be especially surprising to see the Supreme Court avoid providing a definitive answer (or at all). However, if it does decide to speak to these questions, in whole or in part, it would not be particularly surprising to see it claim fidelity to the view, expressed in previous decisions, that intergovernmental dialogue is not determinative of constitutionality, while continuing to let the idea play a role, quietly, in its decision-making. The reason is this: the idea that the political branches have a role to play in actually defining the balance of power, rather than working within the boundaries set by the courts, sits uncomfortably with the traditional view that it is "emphatically the province and duty of the judiciary to say what the law is". 227 It would be surprising to see the Supreme Court openly acknowledge that the political branches have a role to play in the setting of constitutional meaning itself. $^{228}$

\section{Boundaries on Legislative Power}

The Supreme Court has recently acted with restraint in division of powers cases, but it refused to abandon entirely its role in policing the boundaries of federal and provincial legislative power. This leaves two questions: (1) what role, if any, does the Supreme Court intend to play in setting absolute limits on legislative power? and (2) where the Supreme Court is faced with a stark choice between competing federal and provincial legislation, what considerations will it take into account in making its choice? In other words, what role does the Supreme Court

information gained by its department of motor vehicles; the law was acceptable, because it did not impose a duty to act, but merely prohibited conduct).

227 Marbury v. Madison, 5 U.S. (1 Cranch) 137, 177 (1803) (U.S.S.C.).

228 The accuracy of the traditional view has been called into question in recent years, particularly in the United States. For a sample of the academic literature, see Neal Devins \& Louis Fisher, The Democratic Constitution (Oxford: Oxford University Press, 2004); Louis Fisher, Constitutional Dialogues: Interpretation as a Political Process (Princeton: Princeton University Press, 1988); B. Friedman, "Dialogue and Judicial Review" (1993) 91 Mich. L. Rev. 577; Robert C. Post, "Foreword: Fashioning the Legal Culture: Culture, Courts and Law" (2003) 117 Harv. L. Rev. 4; L. Kramer, "Popular Constitutionalism, Circa 2004" (2004) 92 Cal. L. Rev. 959; the articles in (2006) 81 Chi.-Kent L. Rev. 1173 (from a symposium on "The People Themselves: Popular Constitutionalism"); and the articles in J. Balkin \& R. Siegel, eds., The Constitution in 2020 (Oxford: Oxford University Press, 2009). 
intend to play in a system where "the task of maintaining the balance of powers in practice falls primarily to governments"? ${ }^{229}$ These questions may force the Supreme Court to confront even more difficult questions about how different tasks should be allocated "within one and the same policy field". ${ }^{230}$

The recent decision of the Supreme Court in Consolidated Fastfrate is interesting in this regard. In that case, both a federally regulated and a provincially regulated union attempted to be certified as the bargaining unit for the employees of a freight forwarding company. The issue was not the constitutionality of the underlying legislation; the issue, rather, was which legislative scheme, federal or provincial, applied to the company's employees. The Supreme Court was faced with a choice between federal and provincial jurisdiction. If the federal legislation applied, the federally regulated union was properly certifiable as the bargaining unit of the company's employees; if, however, the provincial legislation applied, it was the provincially regulated union that was properly certifiable.

The result was a 6-3 split decision. Justice Rothstein, writing for the majority, said that the freight forwarding company fell within provincial jurisdiction. In reaching this conclusion, he emphasized the manner in which the freight forwarding service was provided. The company fell within provincial jurisdiction, because it merely consolidated and deconsolidated freight, and did not actually physically transport the freight across provincial borders. In contrast, Binnie J., writing for the dissent, said that the freight forwarding company fell within federal jurisdiction. Unlike the majority, he emphasized, citing a previous decision of the $\mathrm{Su}$ preme Court, ${ }^{231}$ the nature of the service provided by the freight forwarding company. The company fell within federal jurisdiction, because it facilitated the shipment of goods across provincial borders.

The majority and minority adopted different interpretative approaches. Departing from recent precedent, Rothstein J. emphasized "historical context". He said, citing Confederation-era documents, that "the preference for diversity of regulatory authority over works and undertakings should be respected, absent a justifiable reason that exceptional federal jurisdiction should apply". ${ }^{232}$ Justice Binnie, in con-

229 Canadian Western Bank, supra, note 8, at para. 24.

T. Hueglin, "The Principle of Subsidiarity" in Ian Peach, ed., Constructing Tomorrow's Federalism (Winnipeg: University of Manitoba Press, 2007), at 212.

231 Alberta Government Telephones v. Canada (Canadian Radio-television and Telecommunications Commission), [1989] S.C.J. No. 84, [1989] 2 S.C.R. 225 (S.C.C.).

232 Consolidated Fastfrate, note 151, above at para. 39; see also paras. 32-39. 
trast, emphasized economic efficiency. He said, citing Canadian Western Bank, that

Canadian courts have never accepted the sort of "originalism" implicit in my colleague's historical description of the thinking in 1867 .... This is not to say that the passage of time alters the division of powers. It is to say that the arrangement of legislative and executive powers entrenched in the Constitution Act, 1867 must now be applied in light of the business realities of 2009 and not frozen in $1867 .^{233}$

On these facts, federal jurisdiction was to be preferred, because checkerboard provincial regulation was antithetical to the coherent and efficient operation of an integrated national transportation service.

The decision in Consolidated Fastfrate may hint at interesting things to come. The Supreme Court was faced with a choice between federal and provincial legislation. Faced with that choice, the Supreme Court seemed unable to agree, not only about the result, but also about the interpretative methodology to apply in reaching that result. (And interestingly, Binnie and LeBel JJ., who co-authored the decision in $\mathrm{Ca}$ nadian Western Bank, appear to have parted company.) This suggests that, although there is a measure of agreement on the Supreme Court that caution should be exercised before imposing absolute limits on jurisdiction, the justices may have difficulty agreeing about what order of government to favour in those cases where they are faced with a choice between an exercise of federal and provincial legislative power. If this is true, it would not be particularly surprising to see disagreements also arise about whether in fact there are still absolute limits on jurisdiction, and (more likely) where those limits lie.

\section{Federal Leadership or Equal Partners?}

Recall the earlier distinction drawn in the academic literature between the narrow sense of cooperative federalism (which envisages a hierarchical relationship between the federal government and the provincial governments) and collaborative federalism (which envisages a nonhierarchical relationship between the federal government and the provincial governments). Which, if either, does the Supreme Court intend to facilitate?

$233 \quad$ Id., at para. 89. 
The answer is that it is difficult to tell. The Supreme Court speaks merely of cooperative federalism, without indicating whether it has in mind a certain amount of federal-provincial hierarchy. The paramountcy decisions provide the most insight into the Supreme Court's thinking, but these decisions send mixed messages.

Two aspects of these decisions seem to reflect a desire to facilitate a hierarchical model of cooperative federalism. Consider the definition of conflict. As noted, the Supreme Court broadened the definition of conflict in two ways: the impossibility of dual compliance test now includes governmental decision-makers, not just citizens; and there will be a conflict both where there is an impossibility of dual compliance or a frustration of federal purpose. This broader definition of conflict affords the federal government a powerful bargaining chip in intergovernmental negotiations about jurisdiction. As Katherine Swinton notes, "[t]he [Supreme] Court's attitudes towards ... the definition of conflict ... affect both the agenda and the tenor of intergovernmental relations.,"234 Consider also the new focus of a paramountcy analysis. By embracing the frustration of federal purpose test, the agenda of the federal government, not just citizen compliance, is now central to any paramountcy analysis. ${ }^{235}$ This seems to indicate that the Supreme Court is particularly concerned to facilitate the achievement of federal goals. It is unclear whether the Supreme Court has these two considerations in mind. However, if it does, this would seem to indicate, at best, that the Supreme Court is content to facilitate a hierarchical, federally dominant form of intergovernmental dialogue about particular exercises of jurisdiction, and at worst, that "cooperative federalism" is merely an ex post facto rationalization for an approach that seeks to privilege federal legislative power.

Two other aspects of these decisions, however, may reflect a desire to facilitate a non-hierarchical, collaborative model of cooperative federalism. First, the Supreme Court indicated clearly in Rothmans that it will be reluctant to "impute to Parliament ... an intention to "occup[y] the field' in the absence of very clear statutory language to that effect". ${ }^{236}$ Second, in Canadian Western Bank, the Supreme Court reiterated (and then applied) the

234 Swinton, "Federalism Under Fire", supra, note 19, at 138. See also Lederman, Continuing Constitutional Dilemmas, supra, note 51, at 315 (noting that the answer to the question "who has the power to do what?" will influence federal-provincial negotiations).

${ }_{235}$ Elliot, "Safeguarding Provincial Autonomy", supra, note 193, at 650.

236 Rothmans, supra, note 102, at para. 21 (citation omitted). 
fundamental rule of constitutional interpretation that, "[w]hen a federal statute can be properly interpreted so as not to interfere with a provincial statute, such an interpretation is to be applied in preference to another applicable construction which would bring about a conflict between the two statutes". 237

In effect, both of these "rules" require Parliament to speak clearly if it intends to pre-empt provincial legislation. This may serve a deliberative function, ensuring that Parliament proceeds cautiously and deliberatively, by at least turning its mind to provincial regulatory interests in a given field of jurisdiction. But it also may serve a dialoguestimulating function. In considering provincial interests, Parliament may be encouraged to consult with the provinces, in order to work out a solution that is acceptable to both orders of government. Failing that, the provinces may be put on notice, giving them the opportunity to pressure the federal government, politically, to negotiate a solution that is acceptable to both orders of government. ${ }^{238}$ It is unclear whether the Supreme Court has these considerations in mind in articulating these "rules", but if it does, this would seem to speak to a court that is anxious, where possible, to facilitate a non-hierarchical, collaborative intergovernmental dialogue about particular exercises of jurisdiction.

\section{The Political Safeguards of Canadian Federalism?}

Notice a fundamental difference in the ideas expressed in the previous two paragraphs. In one paragraph, the focus is the definition of conflict; this reflects an underlying assumption that judicially defined and enforceable limits on federal power are critically important in a federal system. On this view, a court that adopts a broad definition of conflict is placing the provinces at the mercy of a federal government that can displace provincial regulation at its whim. In the other paragraph, little emphasis is placed on judicially defined and enforced limits on federal power; the limits on federal power are assumed to lie in the political process. This touches upon a fundamental assumption that seems to underlie the theory of judicial review described in this paper:

237 Canadian Western Bank, supra, note 8, at para. 75 (citation omitted)

238 See D. Coenen, "Constitution of Collaboration" (2000-01) 42 Wm. \& Mary L. Rev. 1579 , at 1604-18 (recounting the features of "clear statement rules" from the U.S. perspective); and R. Hills, "Against Pre-emption: How Federalism Can Improve the National Political Process" (2007) 82 N.Y.U. Law Rev. 1 (pointing out the deliberative effects of clear statement rules from the U.S. angle). 
this is the idea that the political branches are up to the task of setting the balance of power, and capable of protecting their own interests in doing so.

Is this view defensible? The idea of the political safeguards of federalism has figured prominently in American academic and judicial writing. ${ }^{239}$ However, the idea has received little sustained attention in Canada. ${ }^{240}$ The assumption seems to be that the idea has little purchase in Canada, because there are no (or insufficient) political safeguards in the Canadian federal system. ${ }^{241}$ It is beyond the scope of this paper to consider the accuracy of this view here; I leave that for future work. But if it is true that there are political safeguards operating in the Canadian federal system, this would seem to have important implications for each of the three questions raised above. If there are political safeguards at work, there is a strong argument that intergovernmental dialogue ought to play an important (perhaps even decisive) role in constitutional adjudication. Moreover, the need for the courts to intervene is significantly reduced, and the whole question of what limits the Supreme Court will and ought to place on federal and/or provincial legislative power becomes much less of a concern. Finally, the idea would shed a whole new light on the Supreme Court's current approach to the paramountcy doctrine. The Supreme Court may not be abandoning the provinces to the whim of the federal government, as it might seem, but may indeed be working from the assumption that the provinces have the tools at their disposal to protect their own interests.

239 See the sources cited in note 41. See also Note, "The Lessons of Lopez: The Political Dynamics of Federalism's Political Safeguards" (2005) 119 Harv. L. Rev. 609; and S. Calabresi, "A Government of Limited and Enumerated Powers" (1995-96) 94 Mich. L. Rev. 752.

240 For exceptions, see Swinton, The Supreme Court and Canadian Federalism, supra, note 10, at 41-50; Baier, Courts and Federalsim, supra, note 10, 146-52; and J. Leclair, "Jane Austen and the Council of the Federalism" (2006) 15 Const. Forum 51.

241 See S. Choudhry, "Popular Revolution or Popular Constitutionalism" in R. Bauman \& T. Kahana, eds., The Least Examined Branch (Cambridge: Cambridge University Press, 2006), at 497 (noting that the application of the idea of political safeguards in Canada is "unclear", in light of certain structural differences, but suggesting that Weiler's argument "that "the better technique for managing conflict is continual negotiation and political compromise' deserves closer consideration"); and Ontario Hydro v. Ontario (Labour Relations Board), [1993] S.C.J. No. 99, [1993] 3 S.C.R. 327, at para. 72 (S.C.C.), per La Forest J. (referring to the "very real and effective political forces that undergird federalism", without further elaboration). 


\section{CONCLUSION}

In Canadian Western Bank, the Supreme Court provided rare and rich insight into its theory of judicial review in division of powers cases. Under this theory, the Supreme Court encourages the political branches to take the lead in defining the federal-provincial division of powers, by working out mutually agreeable allocations of jurisdiction in each area of regulatory concern. The Supreme Court primarily limits itself to facilitating intergovernmental dialogue about the division of powers and to resolving the intergovernmental conflicts that result where the political branches fail to agree.

This theory of judicial review is reflected in the McLachlin Court's division of powers decisions. It is reflected overtly in those situations where the Supreme Court is asked to consider the constitutionality of a legislative measure evidencing some measure of intergovernmental agreement about jurisdiction. But it is also reflected, albeit less overtly, in the overall approach to the division of powers. Under this approach, the Supreme Court acts with considerable restraint in imposing absolute limits on federal and provincial jurisdiction, by accommodating substantial overlap in jurisdiction, and primarily limits itself to managing overlapping legislation to avoid conflicts in operation.

This theory of judicial review raises a number of interesting questions, some of which I outlined in the final section of this paper. The Supreme Court has indeed given constitutional law scholars good reason to care again about the division of powers. ${ }^{242}$

242 See MacKay, "The Supreme Court of Canada and Federalism", supra, note 3 (asking whether constitutional law scholars do, and should, care again about federalism). 
